\title{
تمظهرات تداولية في البلاغة العربية
}

\section{Pragmatic aspects in Arabic rhetoric}

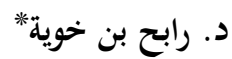 \\ *جامعة محمد البشير الإبراهيمي، برج بوعريريج، الجزائر \\ ra.benkhouya@yahoo.com
}

ملخص

تهاف الدراسة الحالية إلى مقارية التمظهرات (أو الخصائص) التّاولية في البلاغة العربية، المُتمركزة في صميم

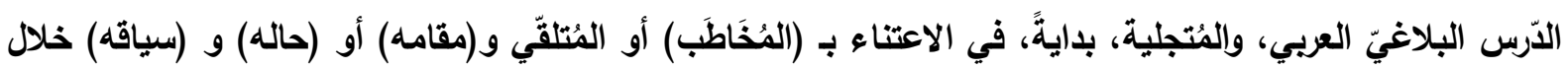

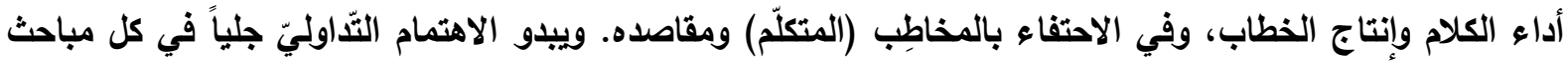

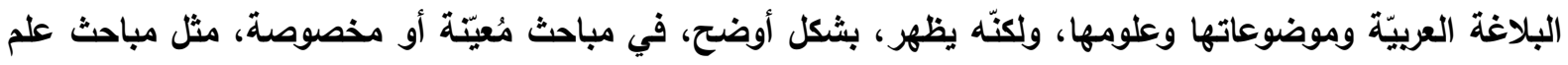
المعاني. ولم يكن الاهتمام غائباً أيضاً عن أذهان من يُمارس البلاغة، بطريقة من الطرائق، تنظيراً أو توصيفاً أو تحليلاً

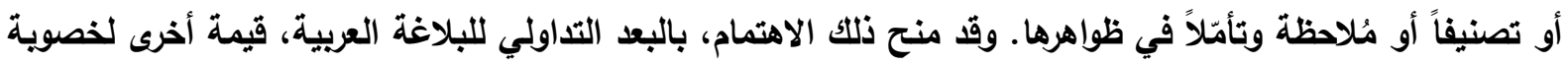
الارس البلاغي وحيويته. كما تهدف الدراسة إلى تقريب المنهج التداولي من التراث البلاغي العربي، والاستفادة من فن أدواته في الدرس والقراعة، ومد جسور من المعرفة البلاغية بين المعطيين الغربي والعربي. كلمات دلالية: التداولية؛ اللسانيات؛ البلاغة؛ اللغة؛ الخطاب؛ السياق.

\section{Abstract}

The study aims at approaching rhetoric and dialectical styles in the choice of words and expressions in Arabic, depending on audience, situation and contexts. Arabic rhetoric style is present almost in all subjects and research related to rhetoric studies and poetry in general and semantics in particular. It is also part of the interests of those who practice rhetoric theoretically, analysis, classification, observation and contemplation of these phenomena. The attention to Arabic rhetoric style gave another value to the creativity and vitality of the rhetorical lesson. The study also aims at bringing dialectic approach closer to Arabic dialectical heritage, using its tools in reading and establishing bridges between Western and Arabic rhetoric styles.

Keyword: Arabic rhetoric; Arabic language; Arabic style; Arabic discourse; lingual context; linguistics; pragmatic style. 
يمثّل الاهتمام أو الاثتغال التّّاوليّ في البلاغة العربيّة موضوعاً جديراً بالمقاربة العلمية. وإذا كان لا

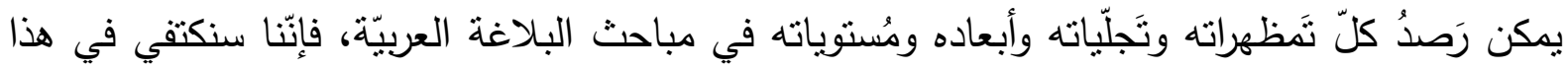

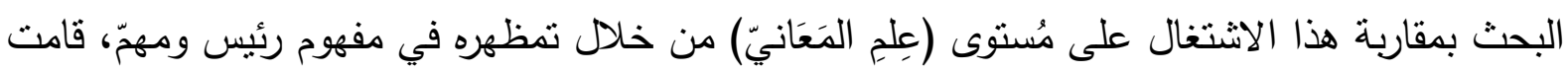

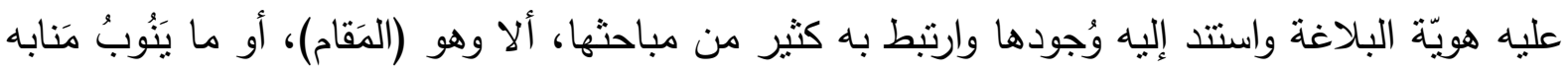

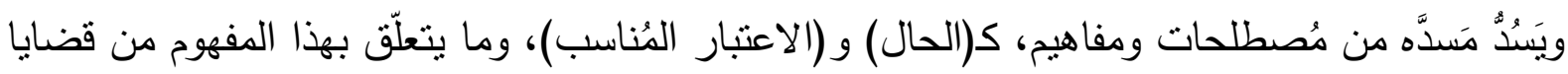

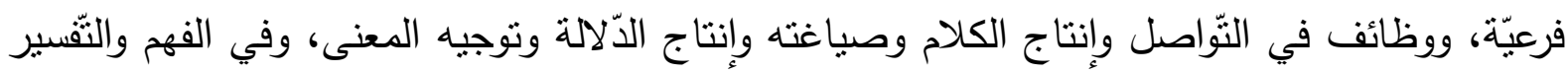

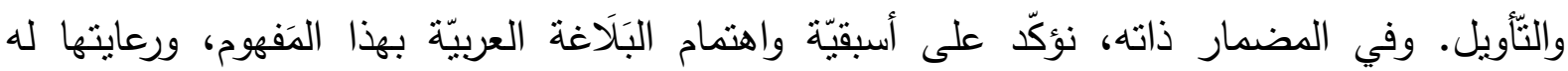

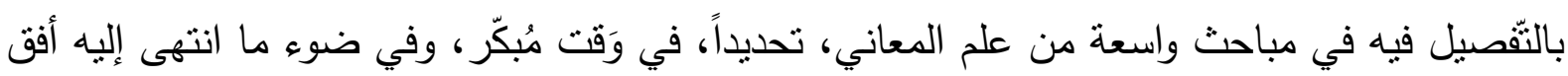

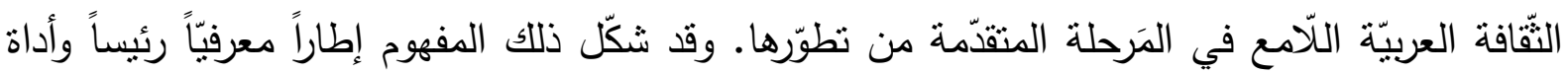

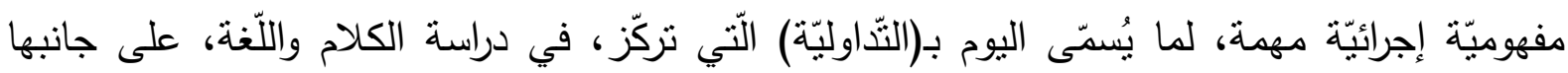

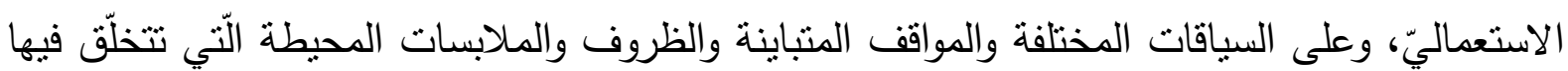
اللّغة وتؤدّي في طيّّاتها وظيفتها.

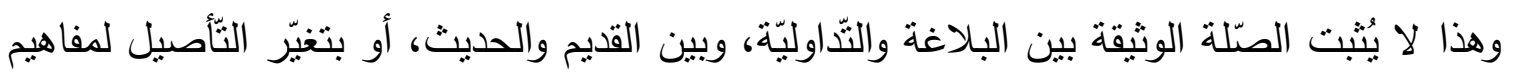

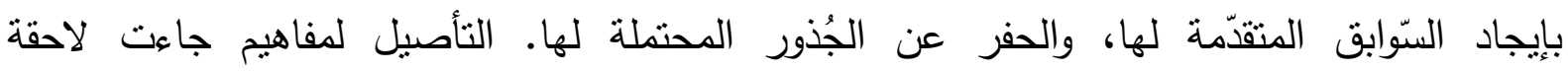

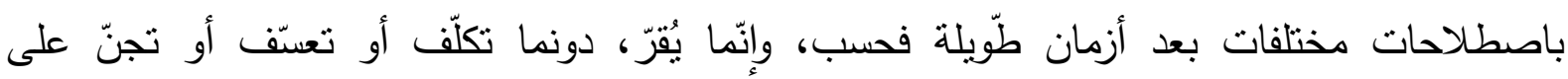

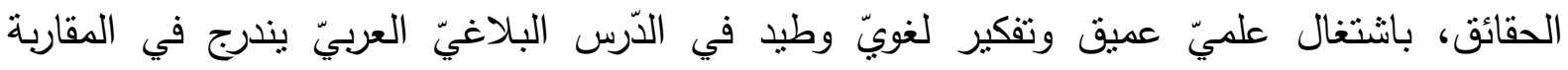
التداولية، وذلك من منظور لغويّ وحضاريّ ثقافيّ خاصّ.

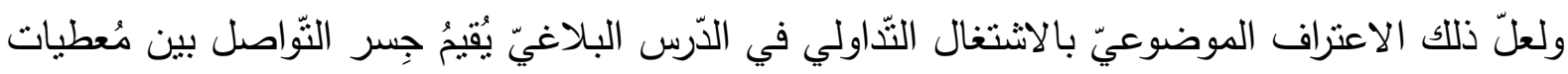

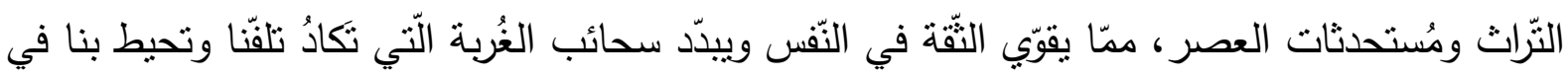

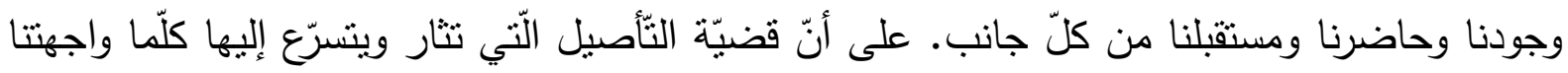

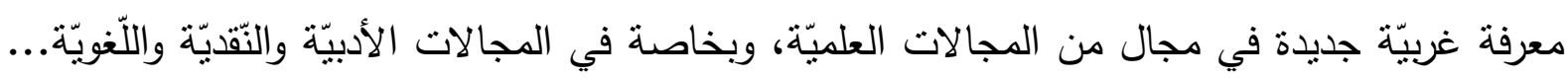

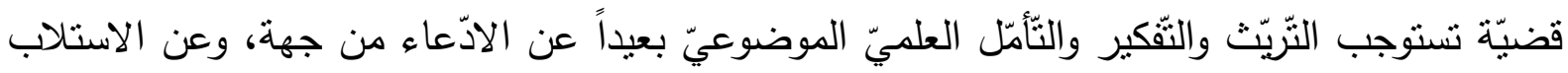

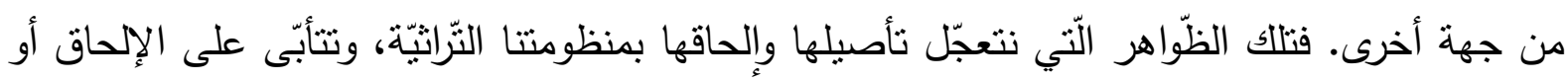

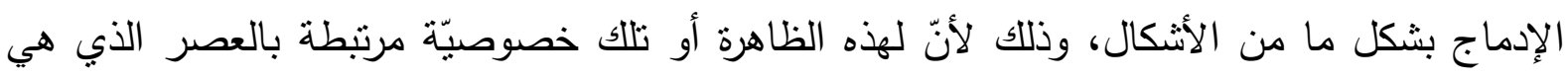

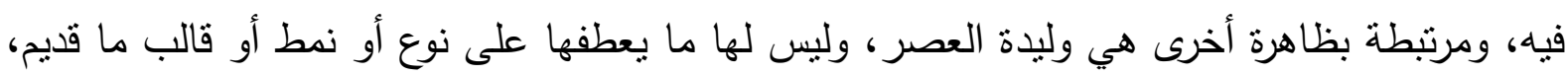

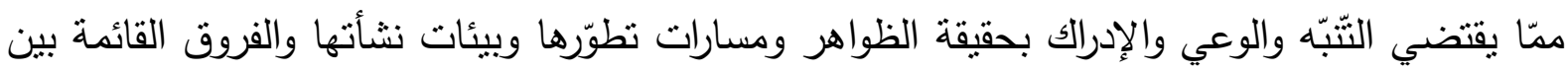

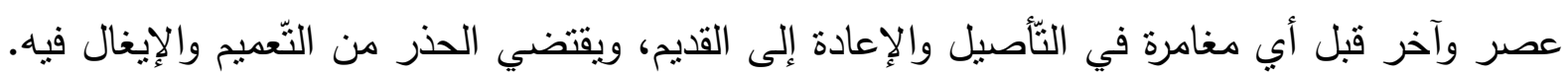
فمبّة ذلك شلل في إعمال الفكر وكسل في البحث وهدر للطاقات ووأد للأسئلة. 
وهنا، يمكن أن نستعير قول أحمد محمد قدور عن الدارسين الَّنين جعلوا (التناص) ظاهرة عامّة

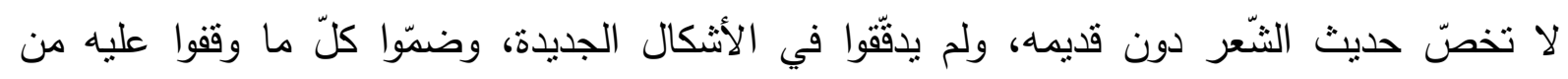

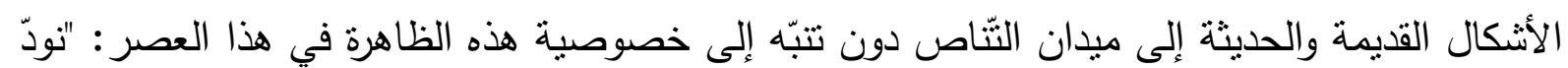

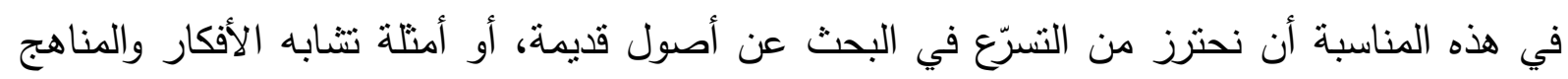

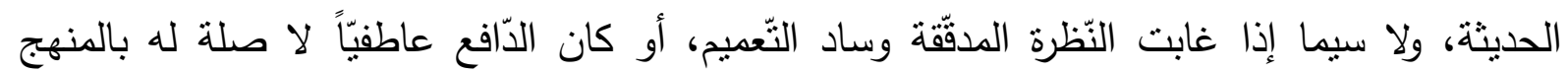

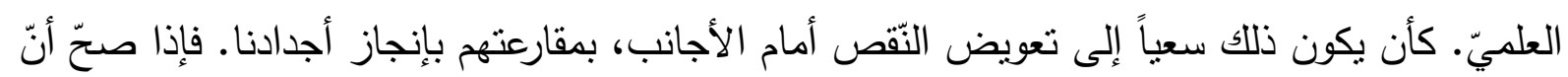

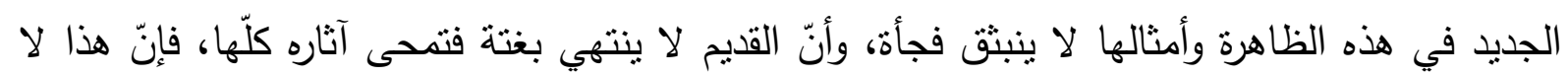

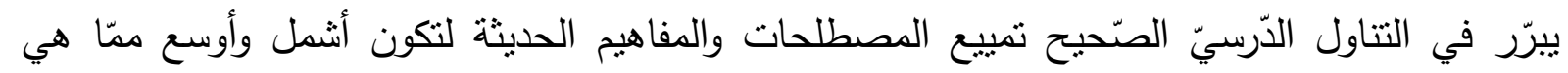

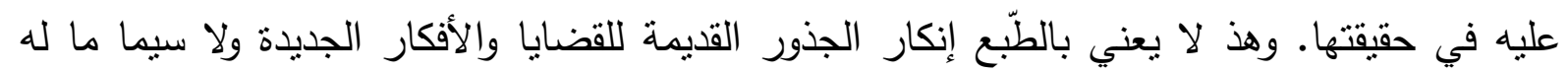

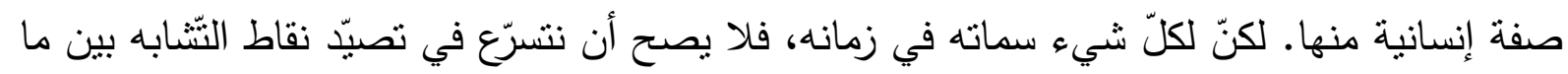

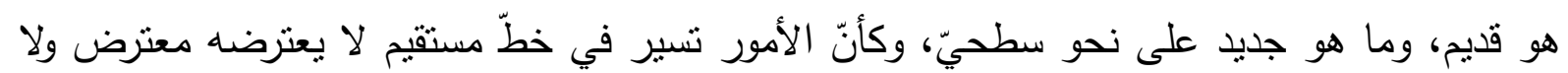

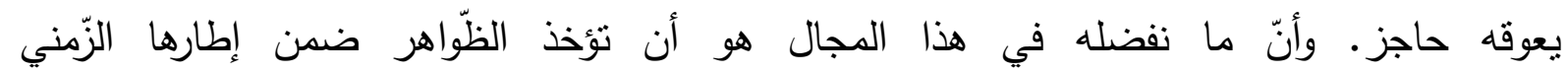

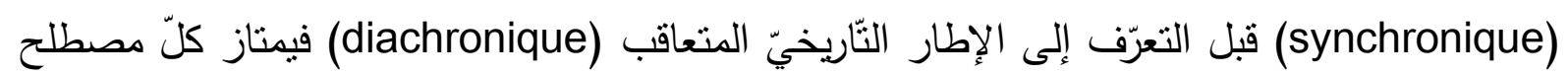

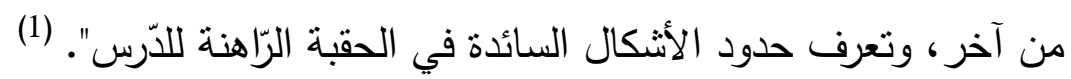

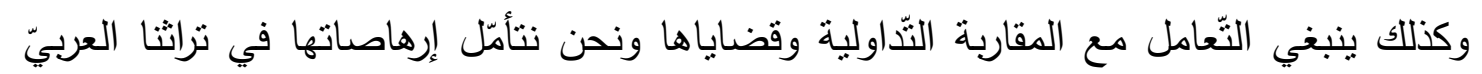

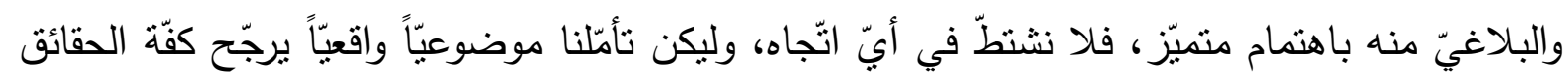
والوقائع على كفّة المشاعر والأحاسيس.

وقد يأخذ ذلك الثّامّل والفحص سمة الحوار، وهو ما يذهب إليه اللّّانيّ واللّغويّ أحمد المتوكّل

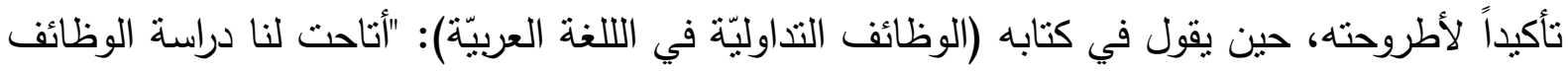
التّّاوليّة الخمس في اللغة العربيّة إطار النحو الوظيفيّ أن نمحّص، إلى حدّ ما، الأطروحة التي دئه دافعنا

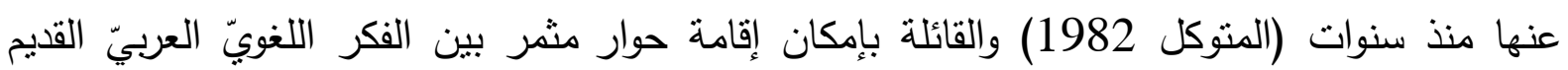
والفكر اللّساني الحديث على أساس القرض والاقتراض، على الرغم من انتماء الفكرين إلى حقلين نظريين

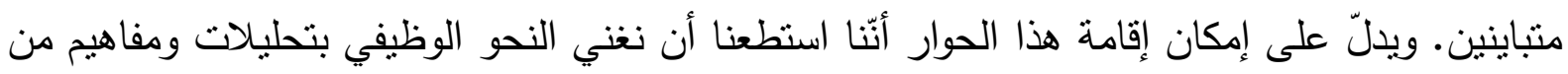

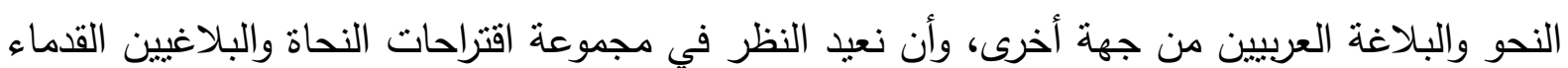

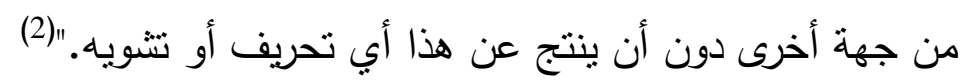

ويأخذ الموضوع شرعيته من أنّ اللغة في التراث العربي، ميّزتها بعض السمات، التي هي من أهم المبادئ التّاوليّة الحديثة؛ فقد تتاول الدارسون القدماء مثنلاً: - - أنّ التكلّم ينمّ لغايات وأهداف أو إثباع حاجات أو الحصول على فائدة. - متسعمل اللغة للأغراض والمآرب ذاتها. 
- - يضفي المتحاورون على الملفوظات دلالات أخرى غير ظاهرة. - - لا تغفل البلاغة العربية ذلك بل إنها تعتمد مبدأ (لكل مقام مقال).

وقد تعددت أثنكال الاهتمام بدراسة الخطاب والإقناع، فتتاولوا نصّ الخطاب في ذاته ودرسوا ما برتبط بالمخاطب وطريقة أدائه، وتلقيه، ومطابقة الخطاب لدقتضى الظاهر ومخالفته إلى غير ذلك من المسائل

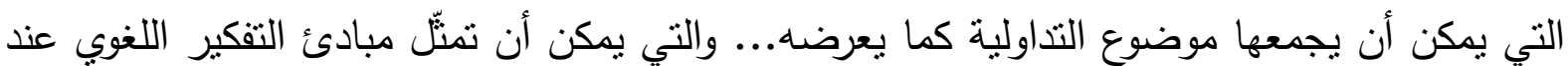

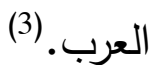

وقد سارعت البلاغة العربيّة في إطار هذا الاشتغال التّاوليّ الأصيل في طبيعتها إلى معالجة

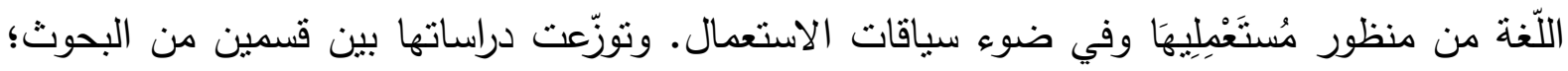

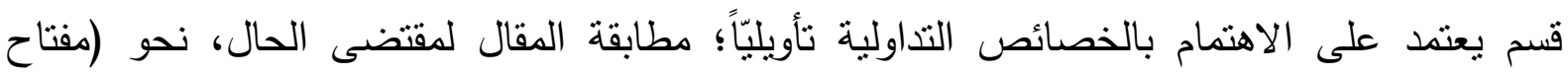

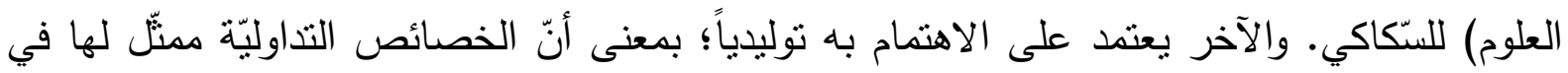

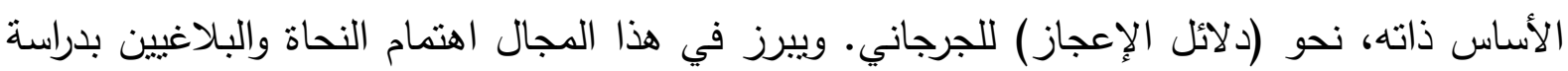

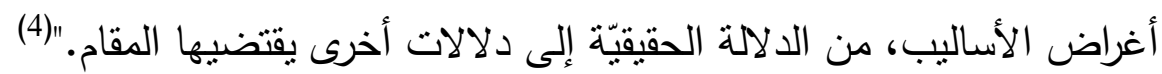
ومن هذا المنطلق العام، يسعى البحث إلى الإجابة عن أسئلة من قبيل: ما علاقة البلاغة بالتداولية؟ وكيف اشتملت البلاغة العربية على أبعاد تداولية، وهل تمثل مفاهيم (المقام) و (الحال) الشتغالاً

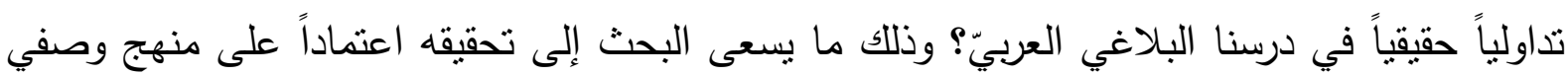

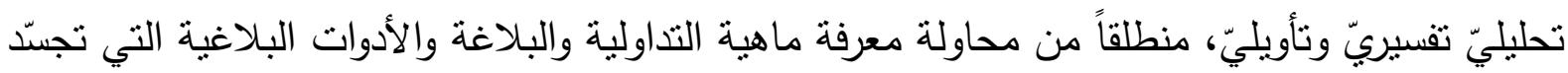

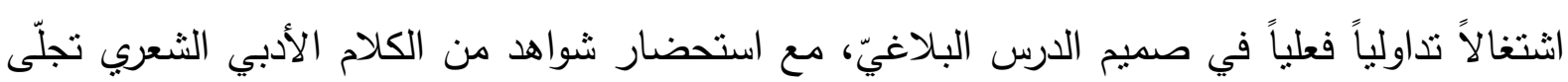

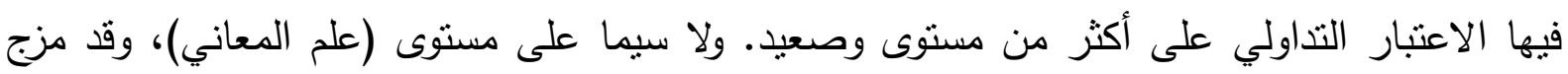

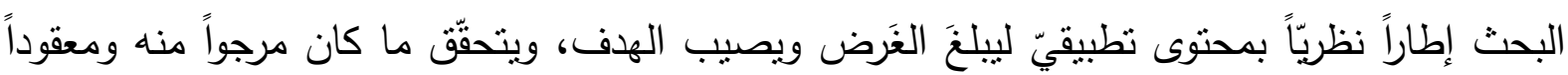

\section{2}

لقد نبّه كثير من الباحثين في التزّاث العربيّ اللّغويّ والنّديّ والبلاغيّ إلى أسبقيّة البلاغة العربيّة إلى الى

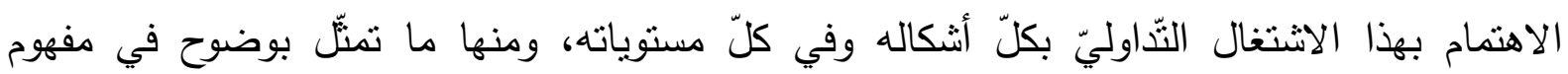

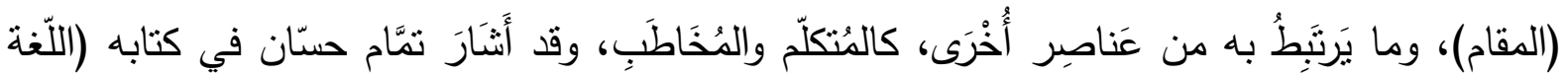

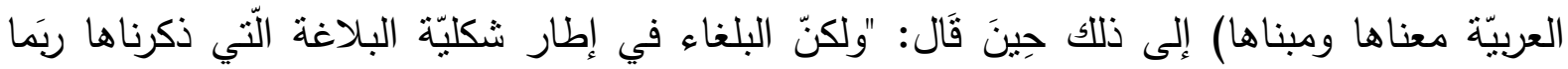

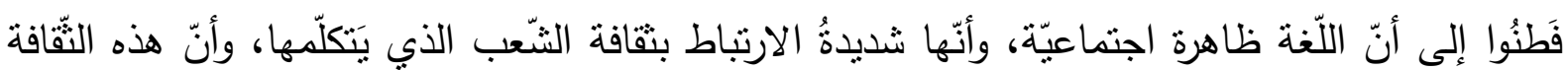

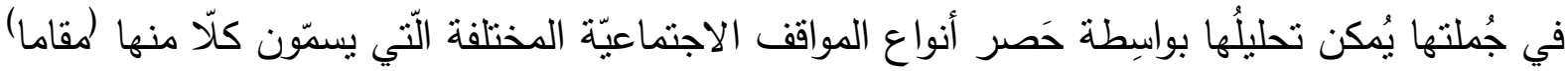




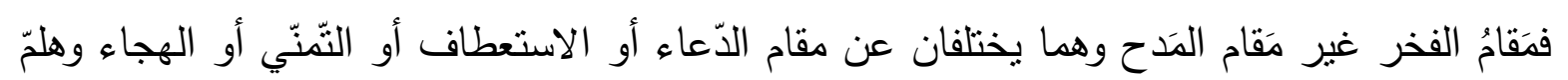

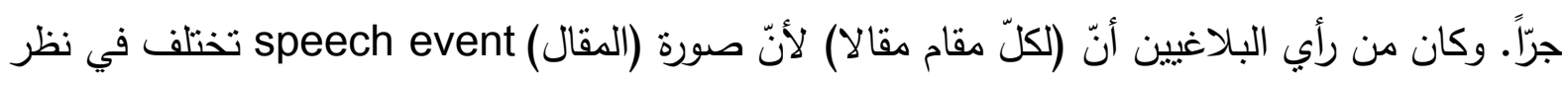

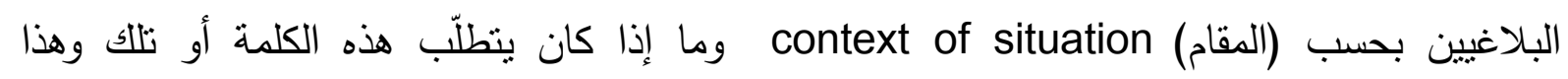

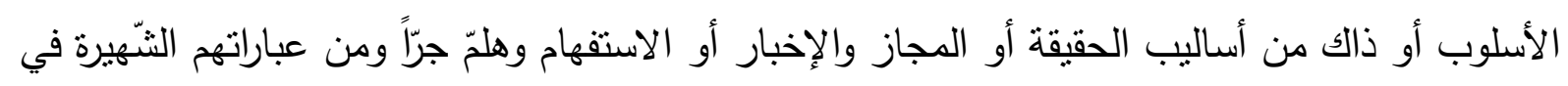

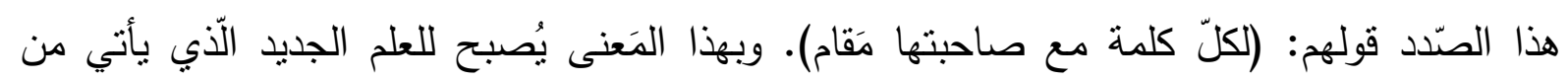

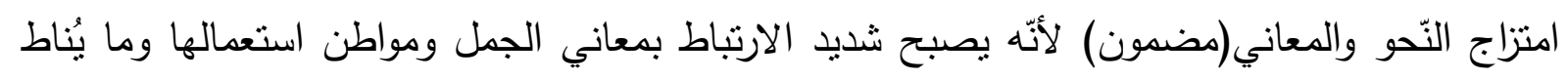

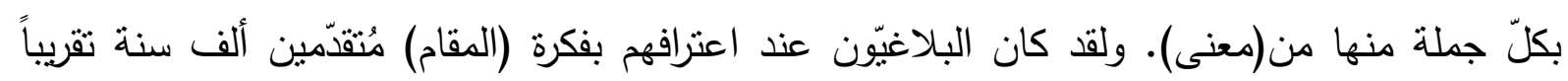

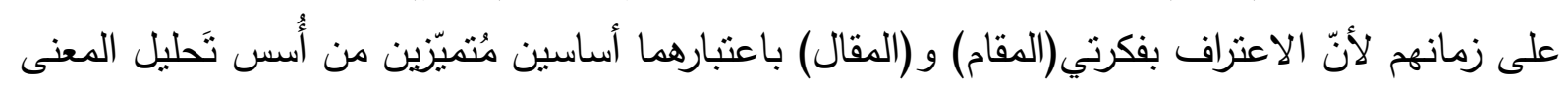

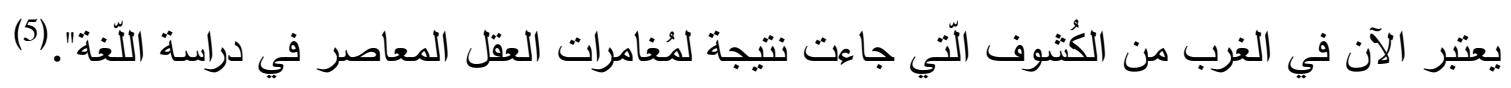

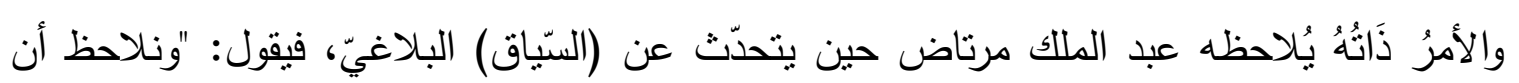

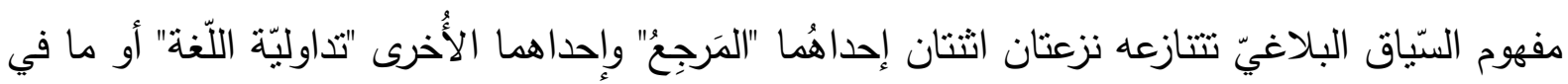

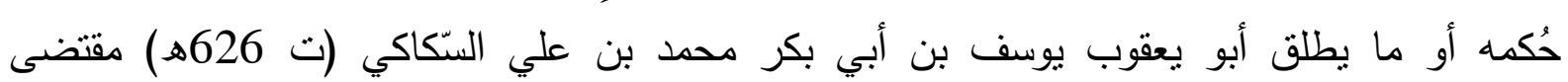

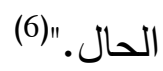

ويتبيّنُ من ذلك أنّ الاشتغال التّداولي في البلاغة من خلال بعض مفاهيم (السيّاق) كـ (مُقتضَى

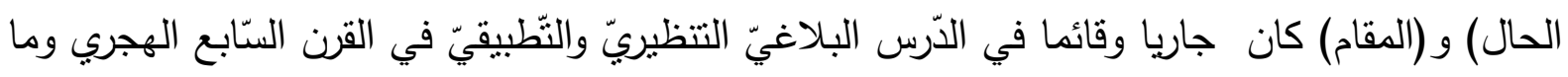

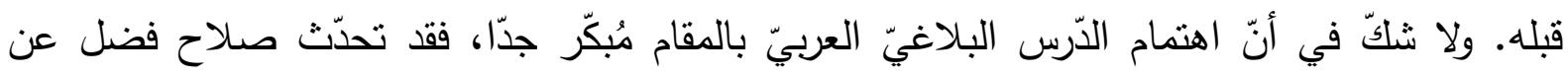

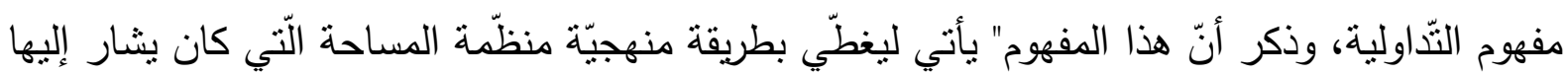

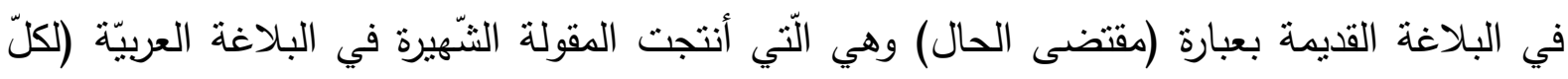
مقام مقال) ". (7) والاطّّلاع على المنجز البلاغي العربيّ في مدوّناته المختلفة يدلّ على أنّ البلاغيين العرب" قد الديّا

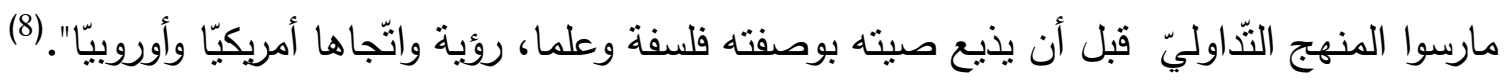
الدّرس البلاغيّ العريّي 2.1

الحقيقة، كما يذهب إلى ذلك محمّد العمري، أنتّا إذا نظرنا في مجمل الإنجاز البلاغيّ العربيّ في

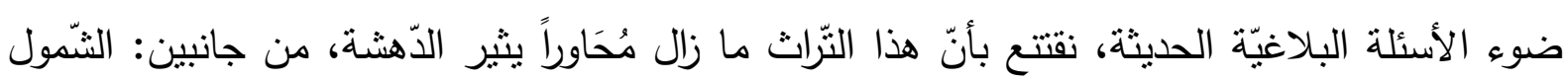

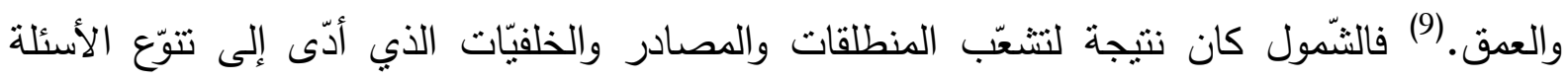

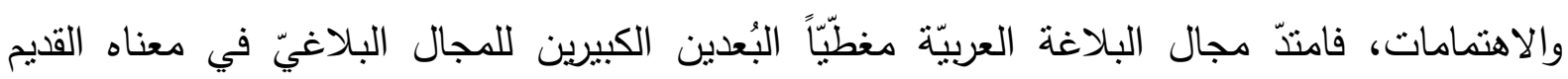

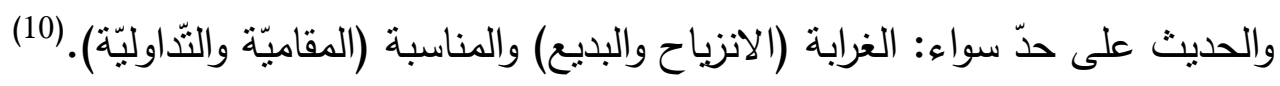

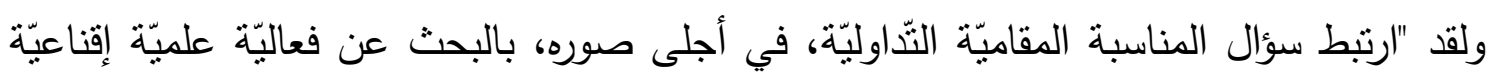

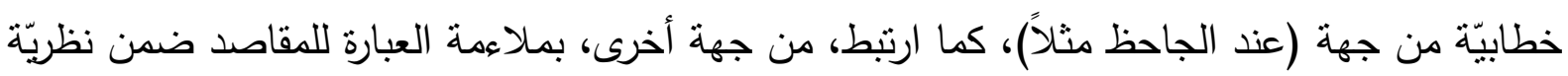


النّظم الإعجازيّة: (أو ما يمكن أن ندعوه "تداوليّة لسانيّة في مقابل التّاوليّة المنطقيّة الإقناعيّة النّصيّة")،

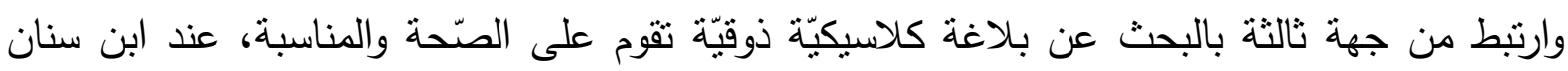

مثنا". (11) من من من

وهذا ما جعل حازم القرطاجنّي (متوفى 684هـ) ينتبه "إلى هذا التّّوع والغنى، فحاول أن يدمج

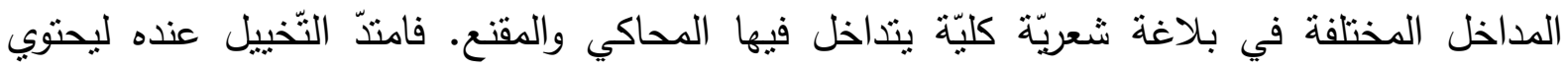

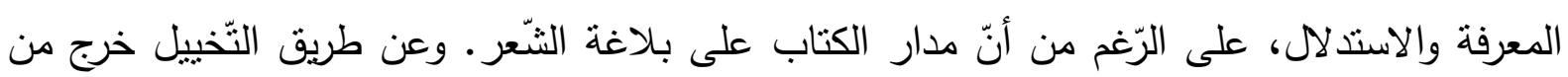

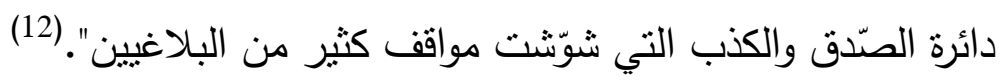

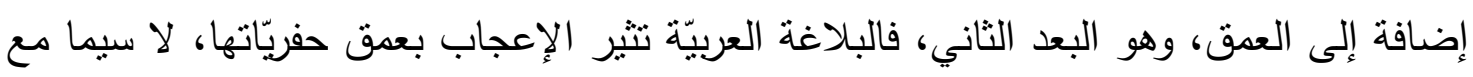
عبد القاهر الجرجاني (471 - 400)هـ/1009- 1078م) في تحليلاته العميقة وتفسيراته الوجيهة التّي كثنف عن بناء الثّّر على المفارقة الدّلاليّة وإدخال عنصر النّّم بوصفه مراقباً للمزيّة الانزياحيّة

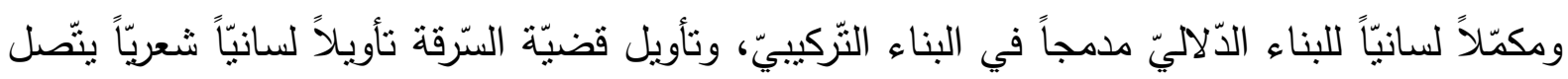

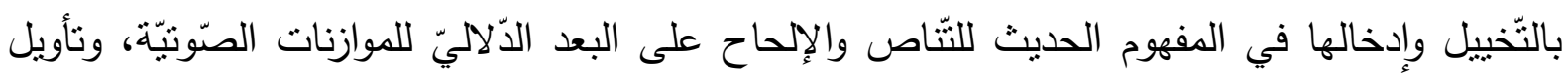

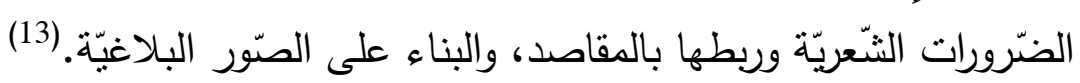
2.2 إن رصد المسار الثّاريخيّ للبلاغة العربيّة يسهم في تقديم صورة واضحة الملامح والقسمات لنشأة

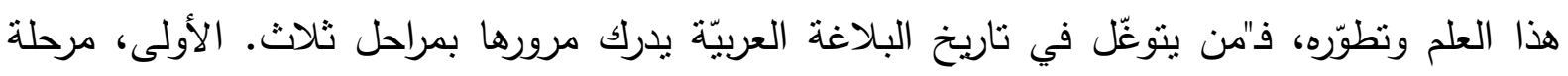

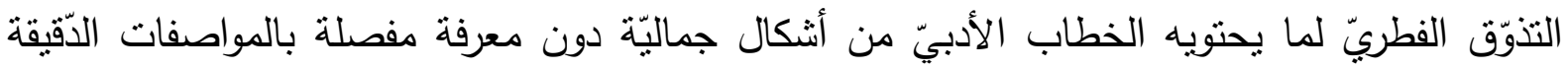

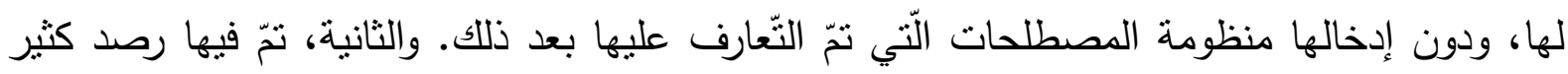

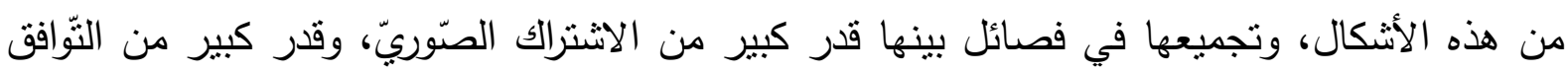
في الإنتاج الدّلاليّ. أما الثالثة فهي مرحلة التّظيم العلميّ التّقيق في تقسيم ثناثيّي: المعاني والبيان والبديع". (14)

فهذه هي المراحل التّطوريّة التّي انتقلت خلالها البلاغة، ويصحّ أن يكون عنوان كلّ مرحلة على التى

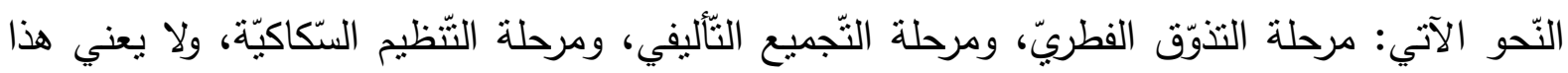

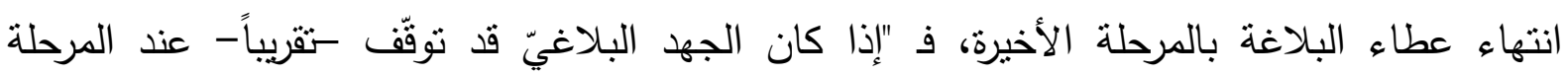

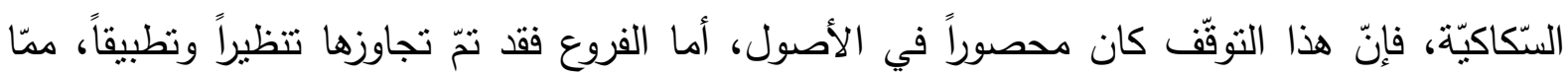
يعني أنّ التوقّف كان (توقفاً متحرّكاً)، على معنى أنّ نابعي الستكاكي قد داروا في فلكه، لكنهم وسعوا

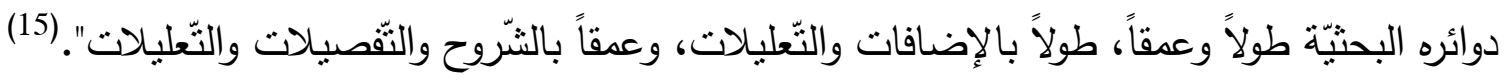


إذا كانت التّاوليّة تعرف في الجهة الغربيّة الأوربيّة والأمريكيّة بـ (pragmatique) و

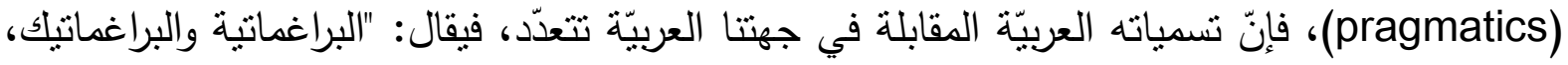
البرجماتية والبراجماتيك، وليس بين هذه الاصطلاحات فرق، بعدّها نقلاً حرفياً للكلمة الأجنيية، وقيل:

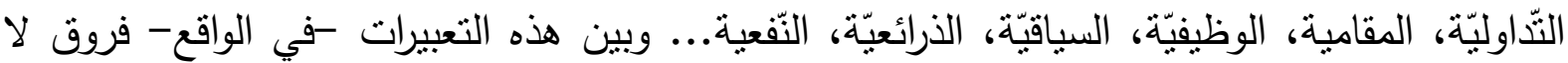

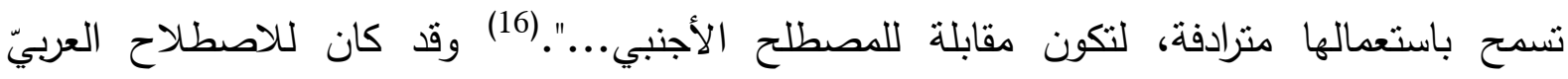
(التّاوليّة) قيمة في التّّوال والاستعمال بين المهنمّين بهذا المجال المعرفيّ منذ أن استعمله أحمد المنوكّل في دراساته المتتوعة، كاللّسانيات الوظيفية مدخل نظري) و (الوظائف التداولية في اللغة العربيّة 1985). إنّ مصطلح النّّاولية (pragmatics)، بالَّفهوم الحديث، يَرجع إلى الفيلسوف الأمريكي نتشارلز

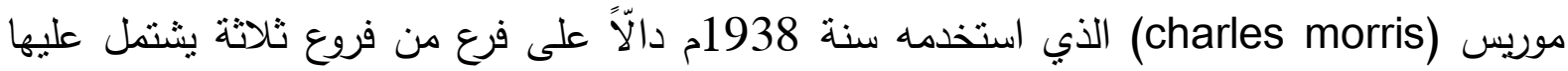
علم العلامات أو السيميّة (semiotics)، وهي كالآتي: علم الثّراكيب (syntactics) أو (syntax)، (sy)، الذي يُعنى بدراسة العلاقات الثثّلية بين العلامات بعضها مع بعض. وعلم الدّلالة (semantics) الذي وهي يدرس علاقة العلامات بالأثياء التي تدلّ عليها، أو تُحيل إليها. والتّاولية التّي تهنمّ بدراسة علاقة

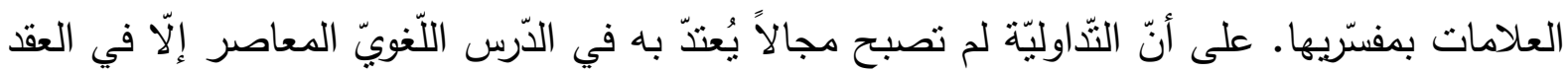

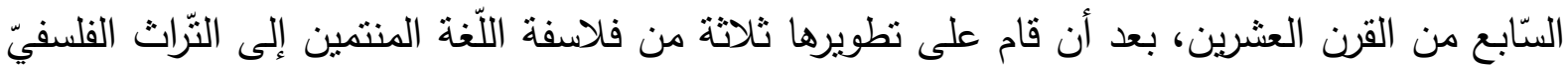

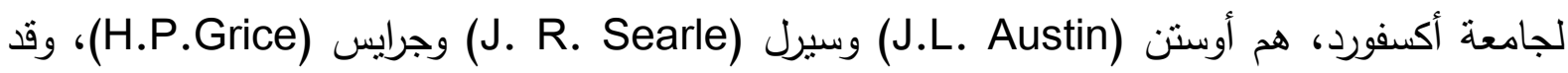

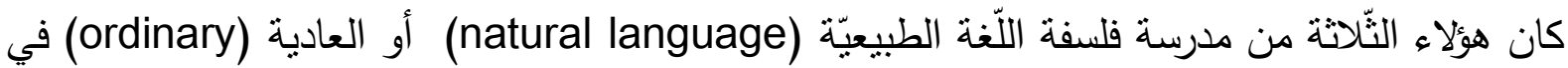
مقابل مدرسة اللّغة الثنّكلية أو الصّوريّة (formal language) التي يمتّلها كارناب (carrnap)، وكانوا جميعا مهتمّين بطريقة توصيل معنى اللّغة الإنسانيّة الطبيعيّة من خلال إبلاغ مرسل رسالة إلى مستقبل

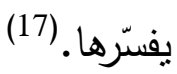

3.2 أثر علاقات التّاولية في تصديد تعريفها

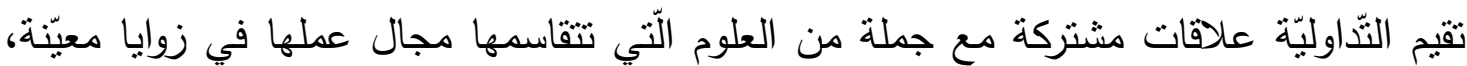
فو(علم الدّلالة) يشاركها في دراسة المعنى، على خلاف في العناية ببعض مستوياته. و و(علم اللّنة

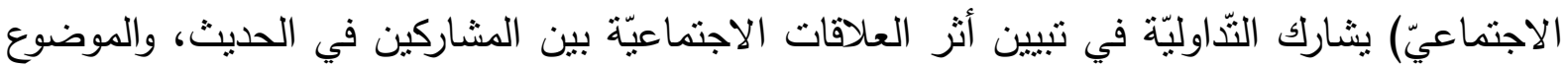

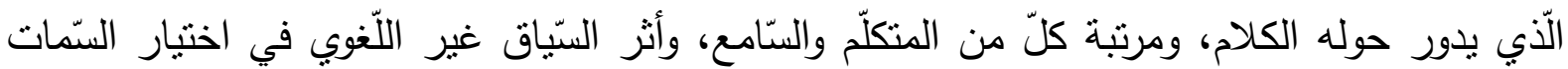
اللّغويّة وتتوّعاتها. و و(علم اللغة النّفسيّ) يشترك معها في الاهتمام بقدرات المشاركين التّي لها أنز كبير 
في أدائهم مثل الانتباه، والذّاكرة، والثتخصيّة. بينما (تحليل الخطاب) يلتقي معها في الاهتمام بتحليل الحوار، ويقتسمان جملة من المفاهيم كالعناصر الإثشاريّة والمبادئ الحواريّة. (18)

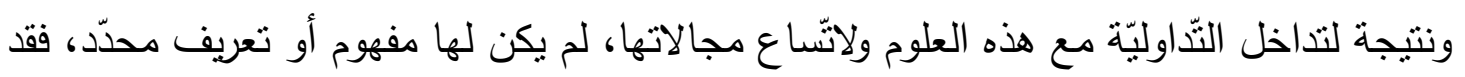

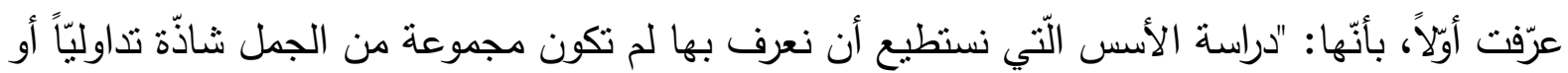

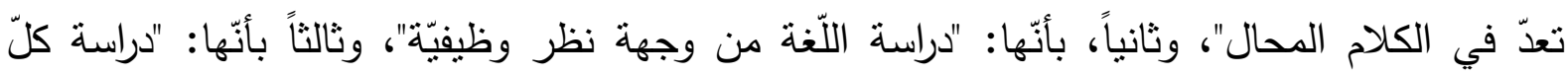

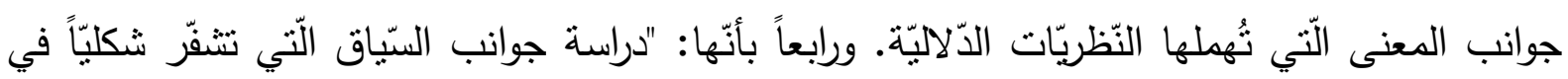

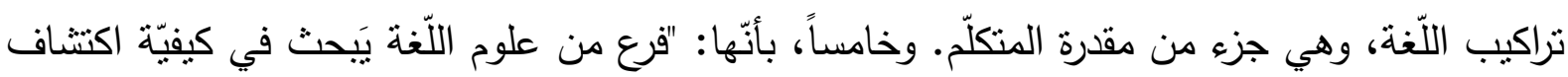

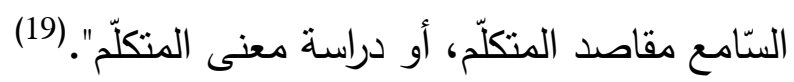

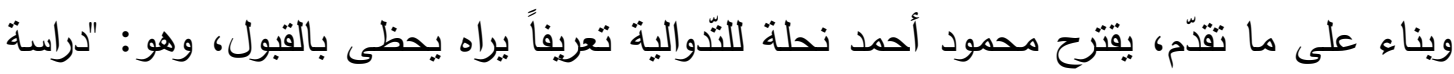

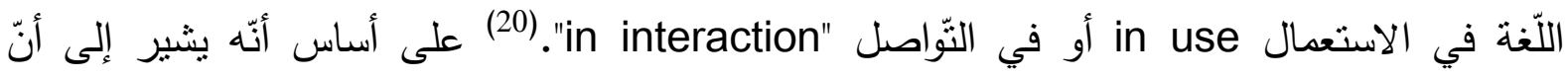

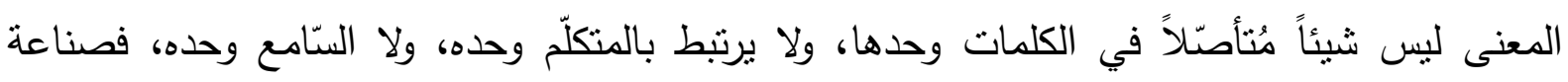

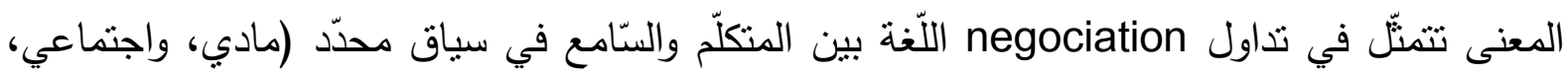
ولغوي) وصولاً إلى المعنى الكامن في كلام ما". (21)

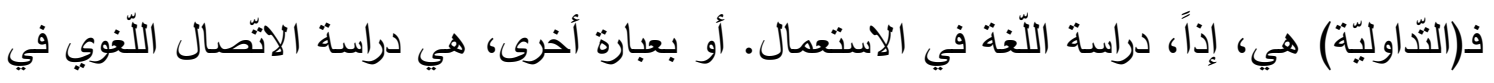

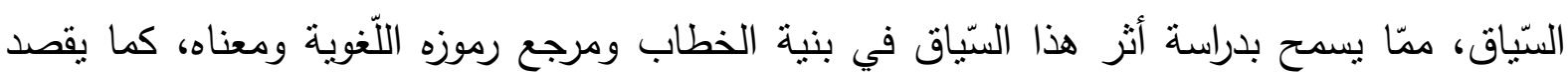

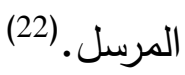

ويتّضح من ذلك، أنّ التّاوليّة (pragmatics)، كدراسة للّغة، تثقدّم" لا بوصفها نظاماً أو بنية، بل على نحو ما نستعمل في المواقف الاتّصاليّة المختلفة (واقعيّة أو متخيّلة)، أي بوصفها نسقاً رمزيّاً

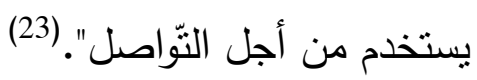

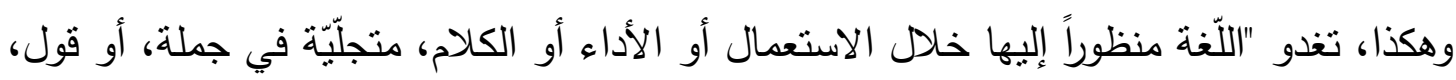

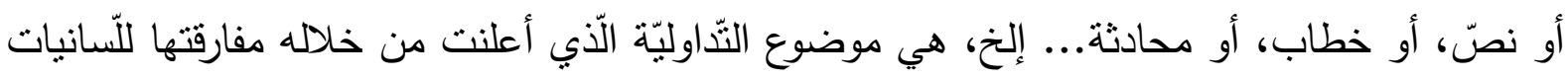

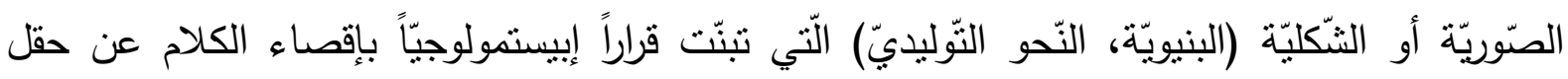

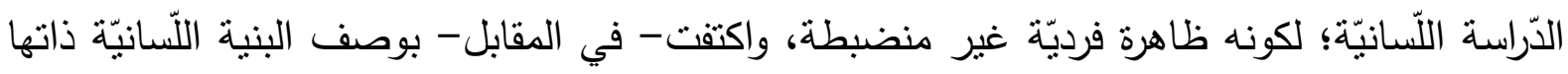

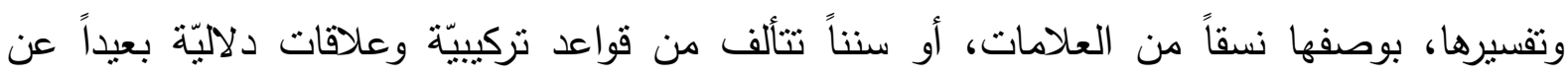

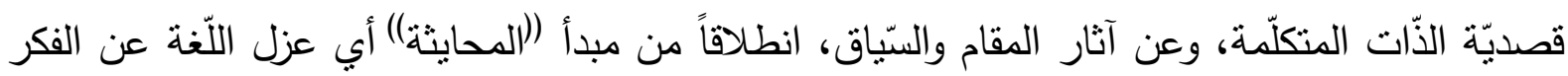
والواقع، ودراستها في ذاتها ولذاتها. (24) وقد انصرفت التّاوليّة إلى دراسة البُعد الاستعماليّ للّنة إلى قدرتها (الخطابيّة) على تحقيق

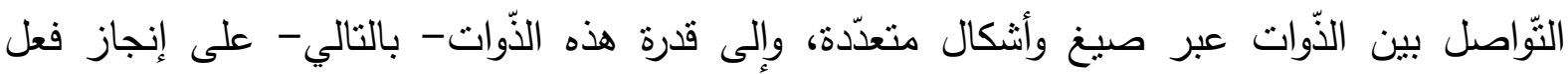
لسانيّ - اجتماعيّ تواصليّ، وفق شروط ومقاصد واستراتيجيّات وتقنيات خاصنّة. (25) 
نستتج ممّا تقدّم من اقتراحات تعريفيّة للتّّاوليّة أنّ كلّ دراسة تتناول (المعنى) اللّغويّ بعيداً عن

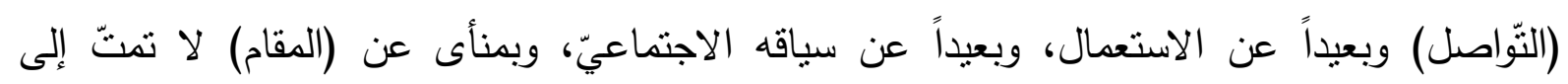

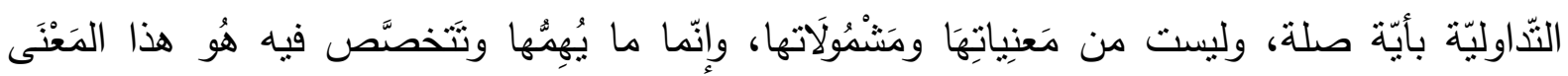

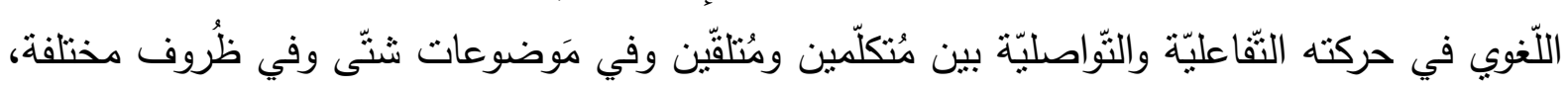

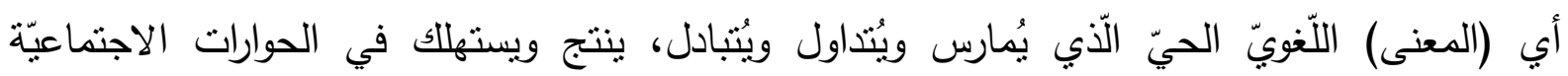

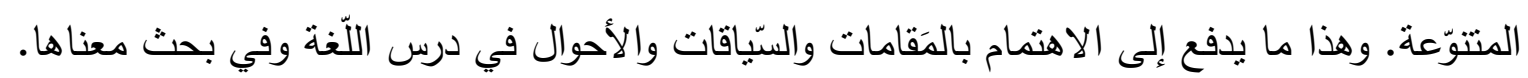

\section{4 4.1 المقام في الدّرس التّاوليَّ الحديث}

يوظّف الباحثون في مجال النّّاوليّات مجموعة من المصطلحات التّي ترد متلازمة وبدلالات

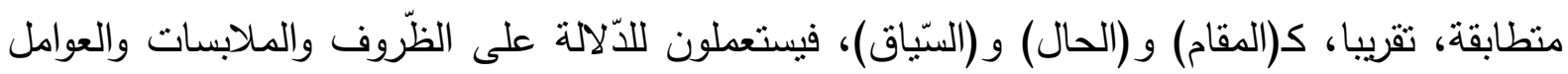

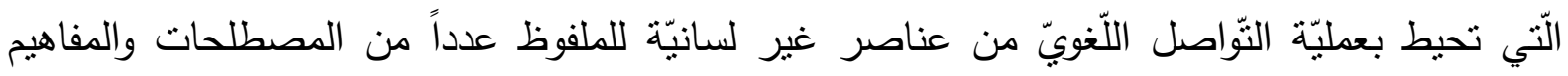

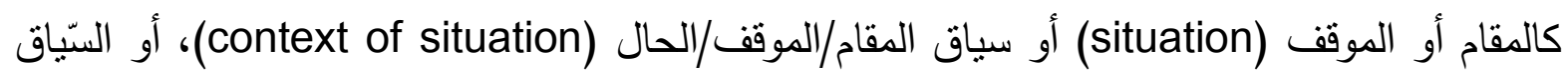

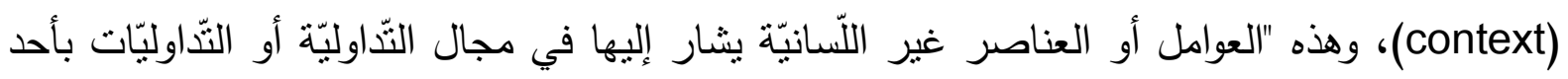

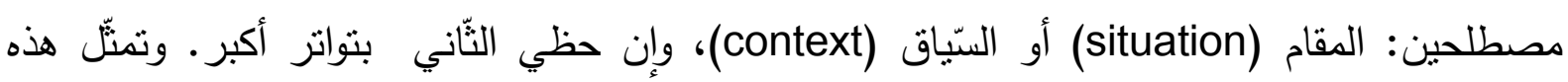

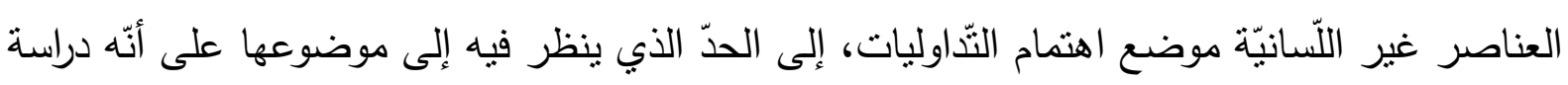

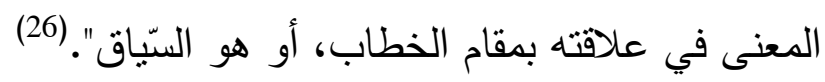

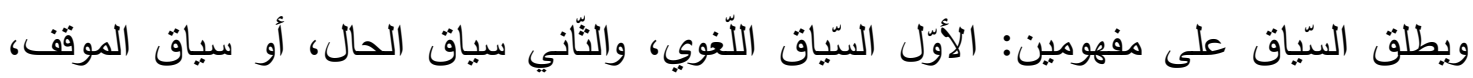

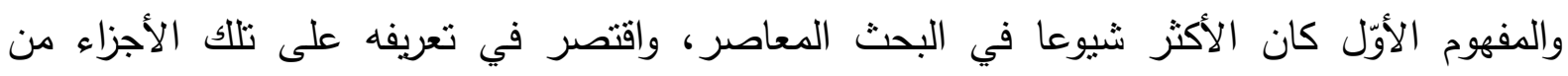

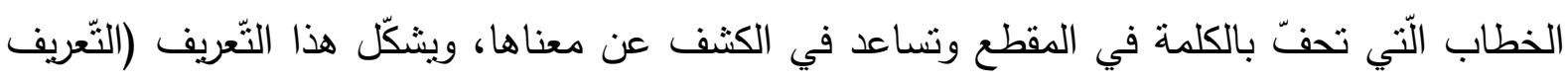

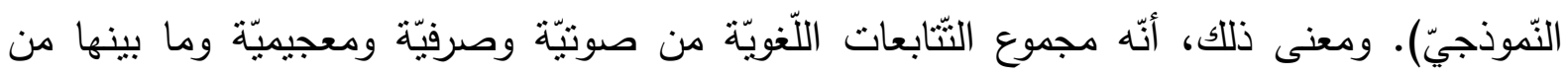

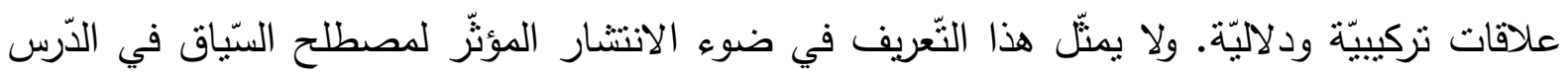

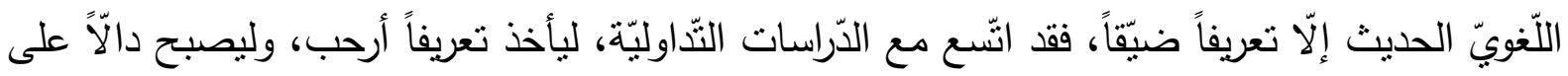

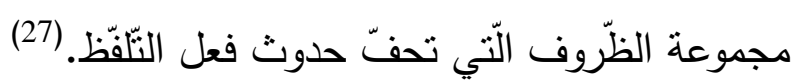

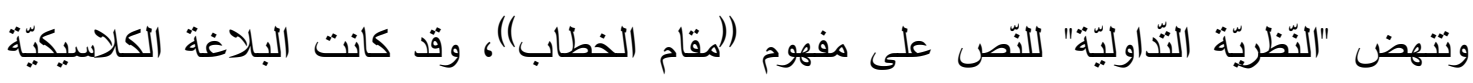

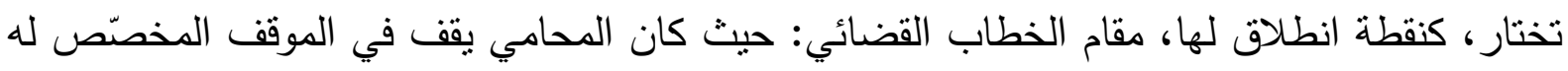
ليتّهم أو ليردّ الاتّهام، وهو يسعى إلى كسب رضاف لهان القاضي. ويضاف إلى هذا المقام مقامان تطبيقان

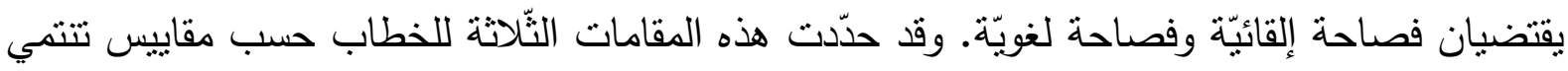

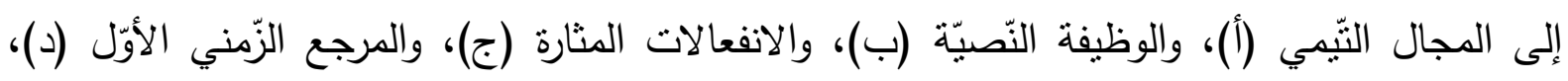
وبذلك نحصل على أجناس ثلاثة: الجنس القضائيّ، والجنس الاستشاريّ، والجنس الاحتفاليّ". (28) 
ولما للسيّاق من تعدّد واتنّاع، فإنّ الاصطلاح على نوعين من السّياق في البحث ضرورة

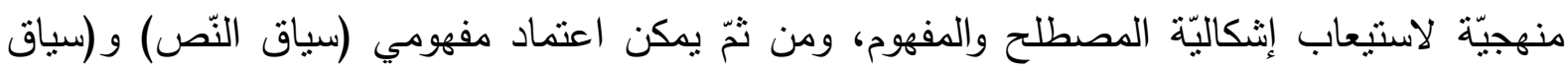

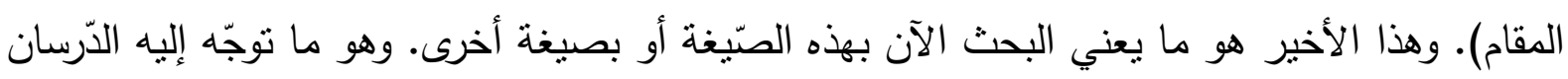

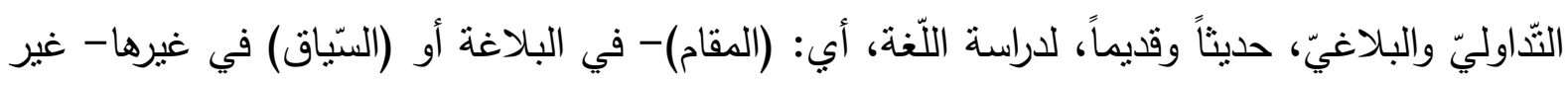

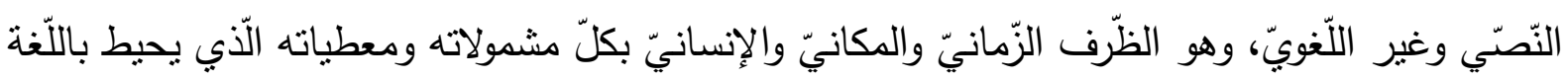

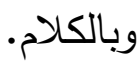

غير أنّ مصطلح (المقام) كان الأكثر تداولاً في الدّرس البلاغيّ العربيّ، ويتتنّع بنفس قيمته

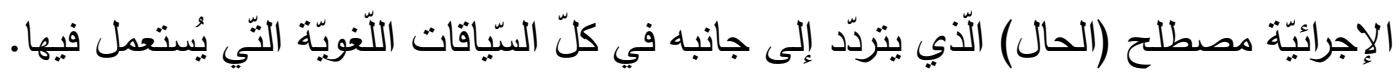

\section{2 المقام في الدَرس البلاغي العربيّ}

نال موضوع (المقام) حيّزاً كبيراً في الدّراسات البلاغيّة العربيّة وفي الدّراسات اللّنوية والدّلاليّة والتّاوليّة الحديثة، ممّا يدعو إلى تسليط الضّوء عليه للكثَف عن مفهومه ووظيفته وأهميّته وقيمته

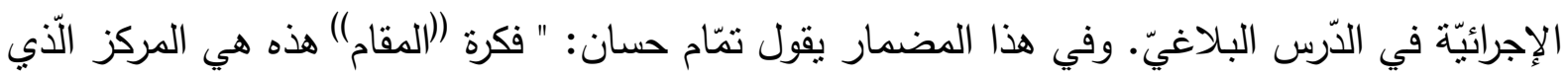

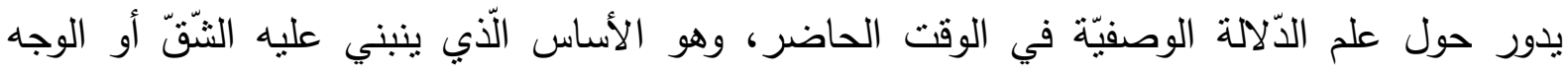

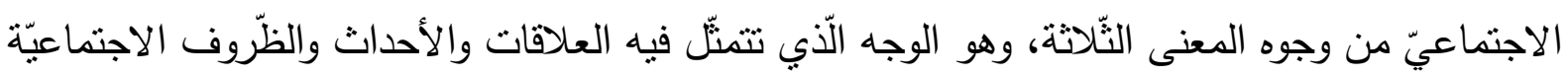
التّي تسود ساعة أداء ((المقال).) ومن المعروف أنّ إجلاء المعنى على المستوى الوظيفي (الصتّوتي

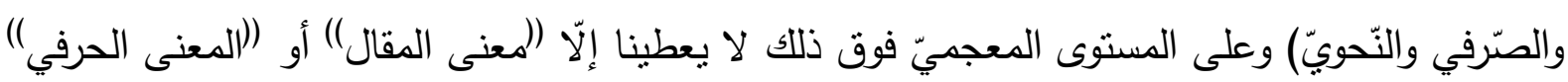

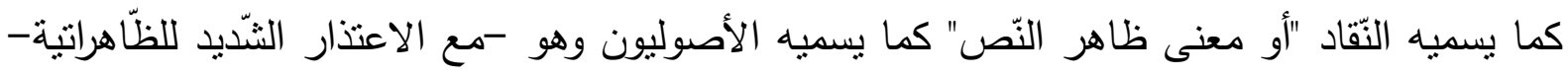

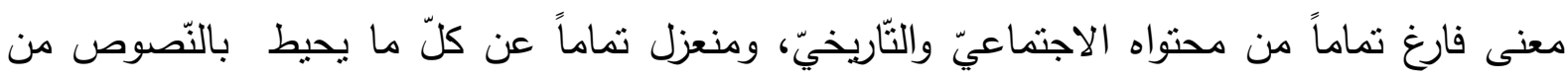

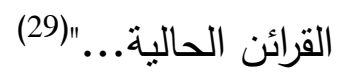

هكذا يوضتح تمّام حسان مفهوم (المقام) وينوّه بالقيمة الإجرائية له وبأهيّته في استجلاء المعنى باستكمال محتواه الاجتماعيّ والثّريخيّ، لعدم كفاية ذلك المعنى المستفاد من المستويين الوظيفيّ والمعجميّ.

و (المقام)، في إطار الدّرس البلاغيّ العربيّ، هو على النّحو الّّبي يحدّده به محمّد العمري، حين

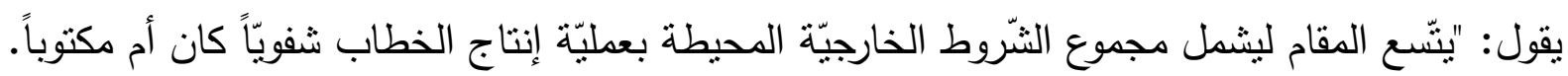

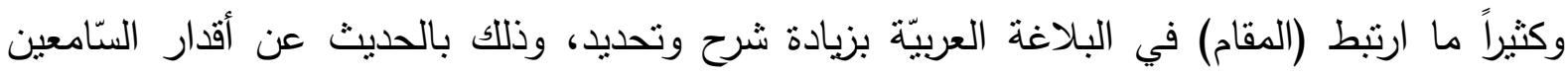

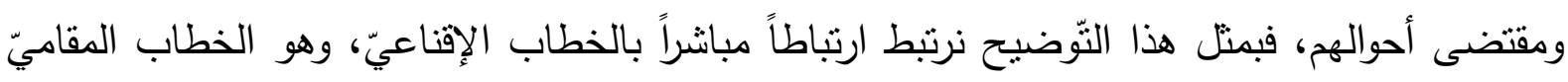

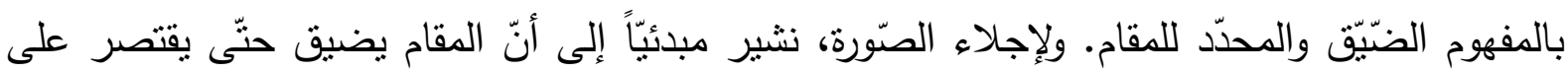

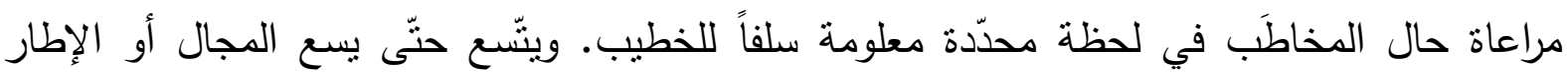

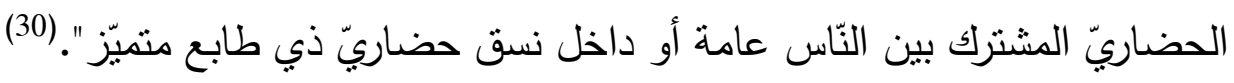


ويستّي محمد العمري المقام الأول مقاماً خاصاً أو خطابيًاً، ويسمّي الثّاني مقاماً عاماً أو مشتركاً؛

أي مشترك بين الثّعر والخطابة، والغالب على مفاهيم البلاغيين حصر المقام في الدقام الخطابيّ.(31)

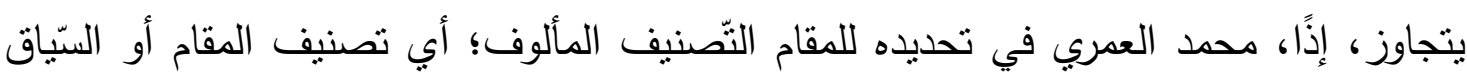

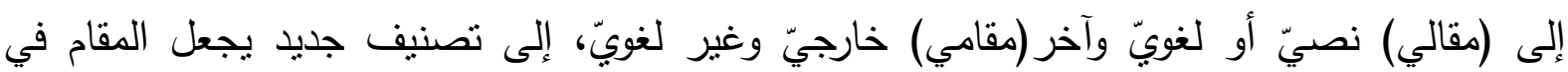

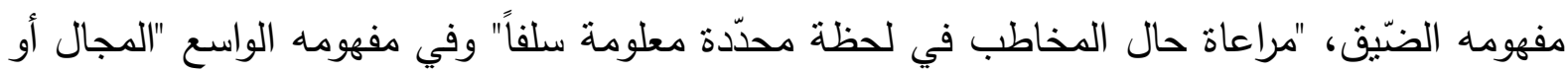
الإطار الحضاريّ المشترك بين النّاس عامّة أو داخل نسق حضاء حضاريّ ذي طابع متميّز ".

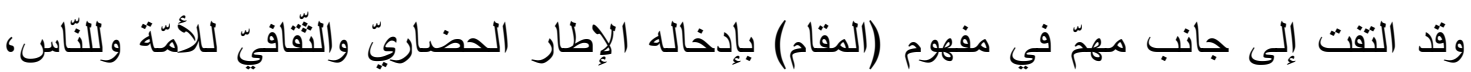

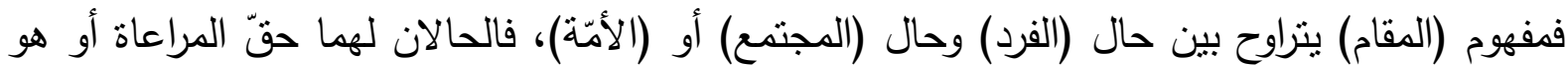
مقتضى حالهما.

وغير بعيد عن ذللك، يذهب تمّام حسان إلى تحديد مفهوم (المقام) على أنّه موقف اجتماعيّ

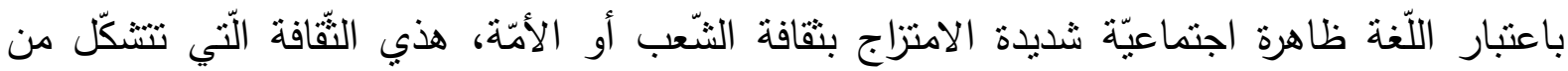

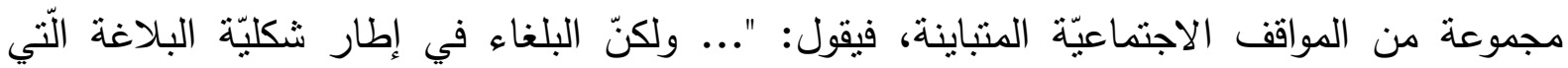

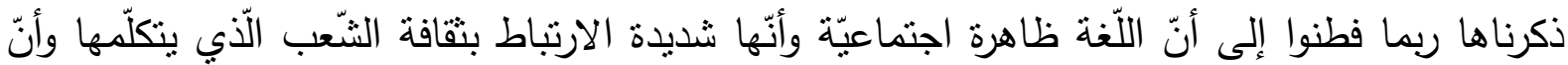
هذه الثقافة في جملتها يمكن تحليلها بواسطة حصر أنواع المواقف الاجتماعيّة الدختلفة التّي يسمّون كلًّ الَّان

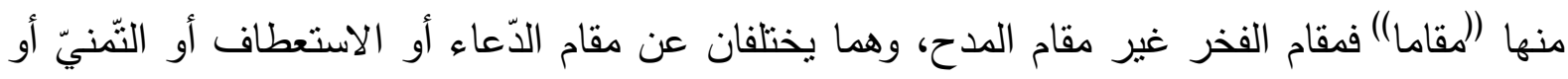

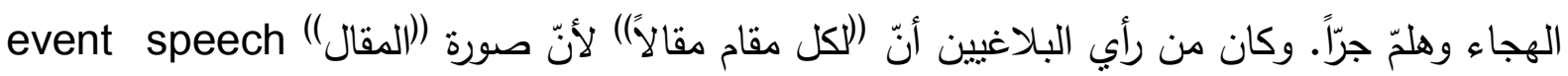

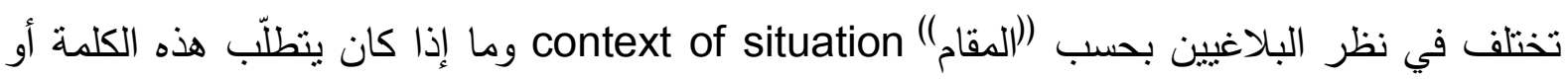
تلك وهذا الأسلوب أو ذاك من أساليب الحقيقة أو المجاز والإخبار أو الاستفهام وهلمّ جرًاً، ومن عباراتهم

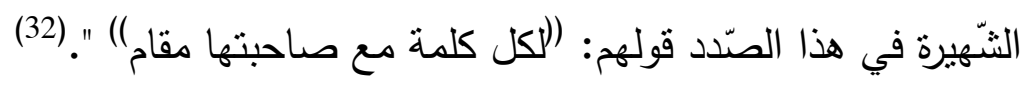

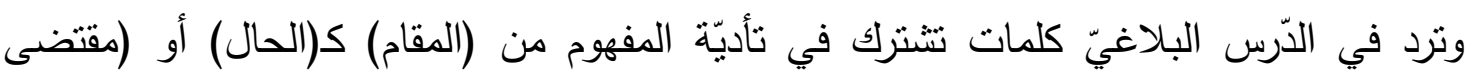
الحال) أثناء تعريف البلاغة أو علم المعانيّ. ففي كتاب (الإيضاح في علوم البلاغة)، يعرّف القزويني (739هـ) البلاغة أو بلاغة الكلام، الباء

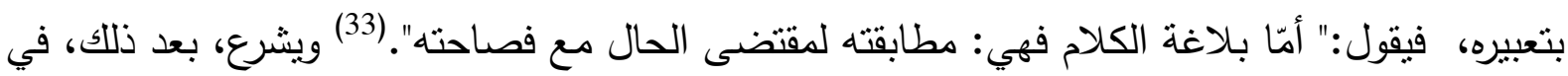

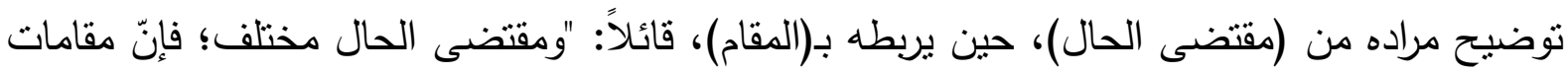

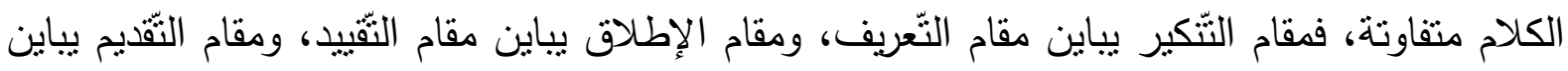

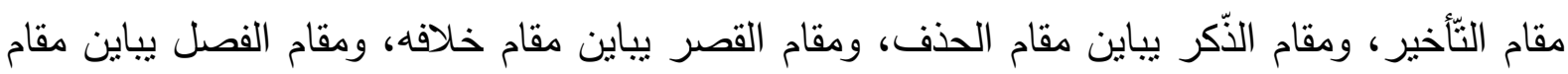

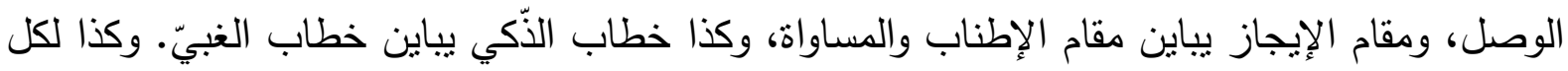

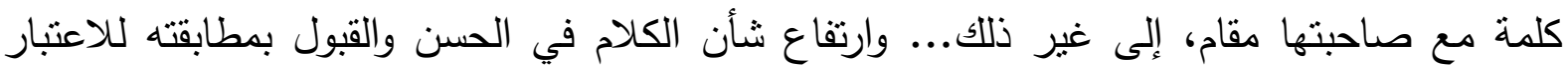

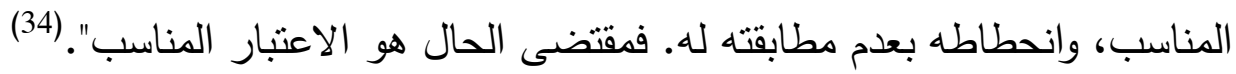


وفي هذا القول تتبغي الإثنارة إلى أنّه يتحدّث عن مقتضيات مختلفات، وعن مقامات مختلفات

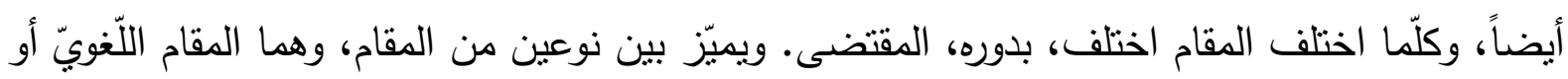

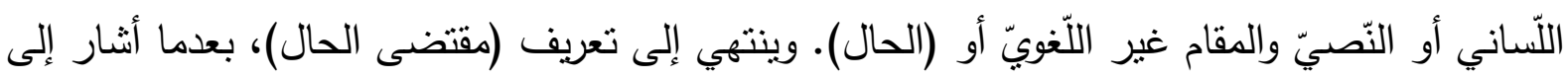

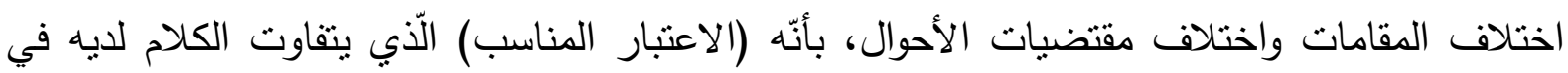
الحسن والقبول بقدر المطابقة له.

وترد عبارة (مقتضى الحال) في موضع ثانٍ، في تعريفه لعلم المعاني بأنّه: "علم يعرف به أحوال

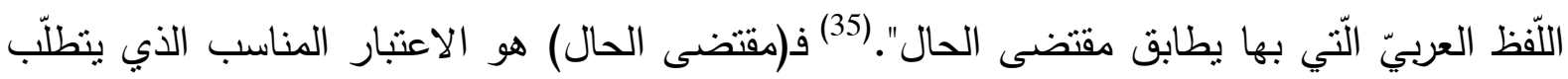

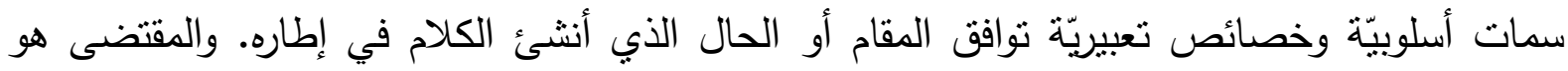

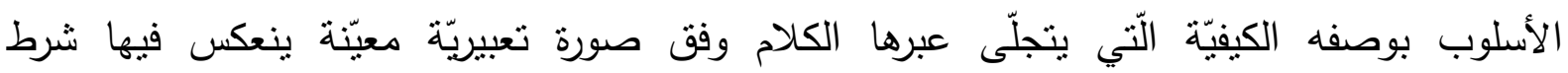

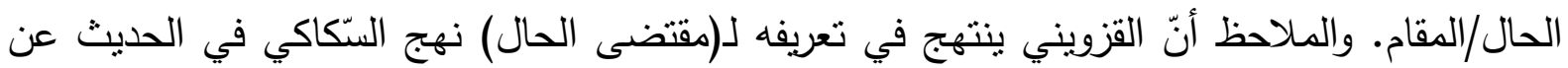

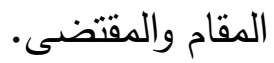
وفي كتاب (مفتاح العلوم) يرد المصطلحان (المقام) و (المقتضى)- ويراد به (مقتضى الحال)حيث يقول السّكاكيّ: "لا يخفى عليك أنّ مقامات الكلام متفاوتة، فمقام التّنكر يباين مقام الثّكاية، ومقام

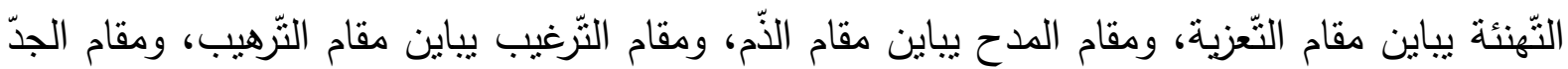

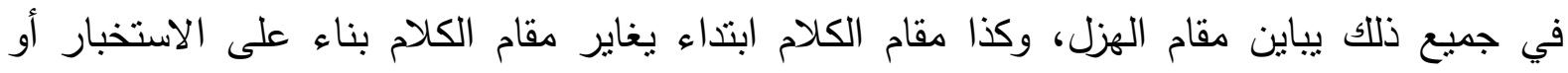

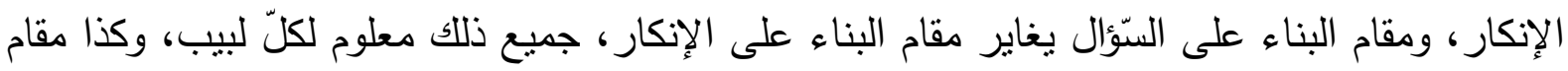

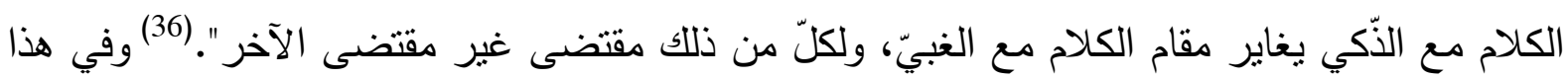
النّص نأكيد على اختلاف المقامات وتباينها وتفاوتها باختلاف المناسبات والمخاطبين.

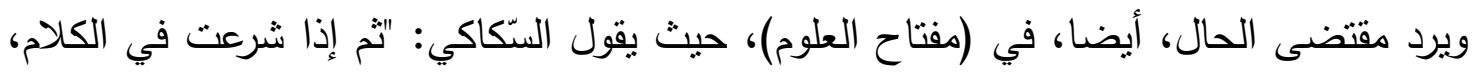

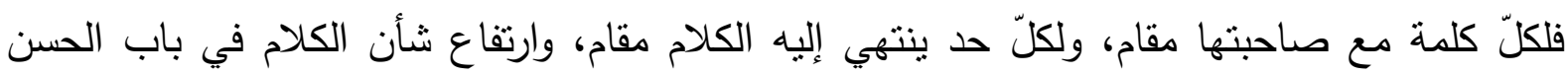
والقبول وانحطاطه في ذلك بحسب مصادفة الكلام لما يليق به، وهو الذّبي نسمّيه مقتضى الحال، فإنهان

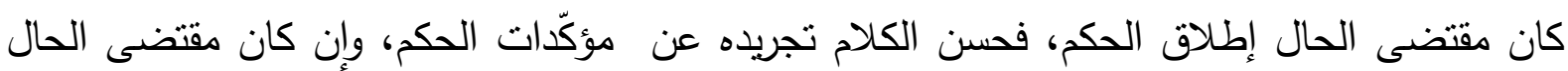
بخلاف ذلك، فحسن الكلام تحاكيه بشيء من ذللك بحسب المقتضى ضعفاً وقوة، وإن كان مقتضى الحال طي ذكر المسند إليه، فحسن الكلام تركه، وإن كان المقتضى إثباته على وجه من دأ بلى الوجوه المذكورة،

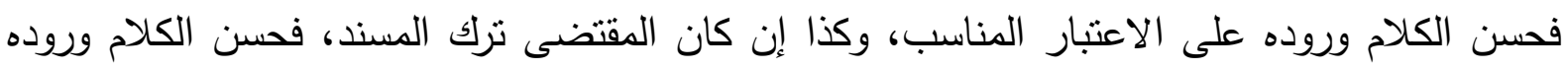

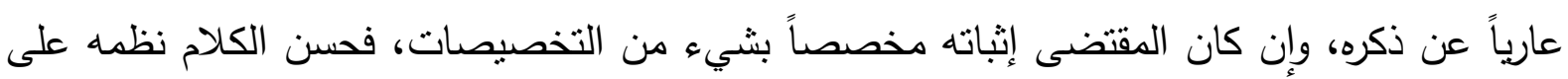
الوجوه المناسبة من الاعنبارات المقدم ذكرها، وكذا إن كان المقتضى عند عند انتظام الجملة مع أخرى فصلها

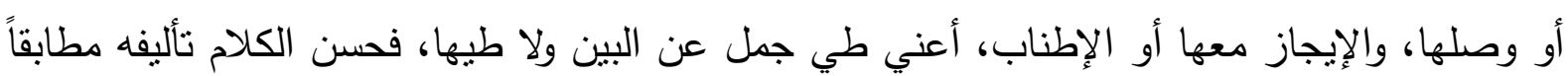

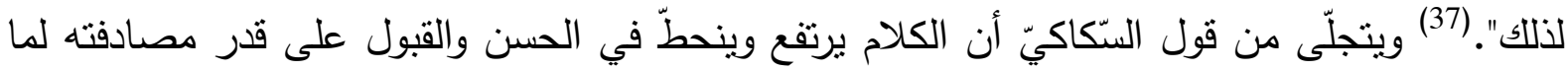
يليق به، و (ما يليق به) هو (مقتضى الحال) وهو (الاعتبار المناسب) كذللك. 


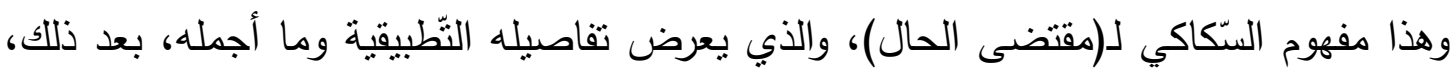

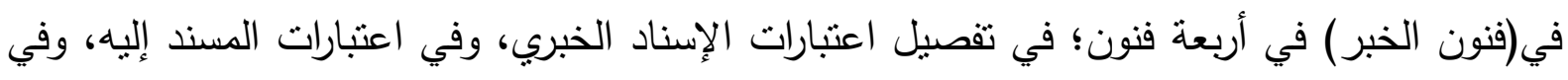
اعتبارات المسند، وفي تفصيل اعنبارات الفصل والوصل والإيجاز والإطناب. وكل هذه المسائل المندرجة تحت مستّى (علم المعاني)؛ العلم الثناني من علوم البلاغة.

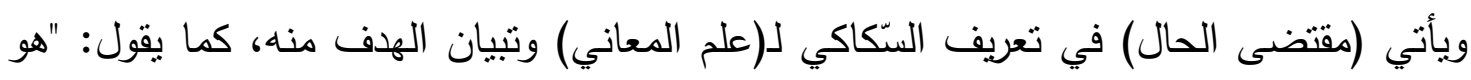

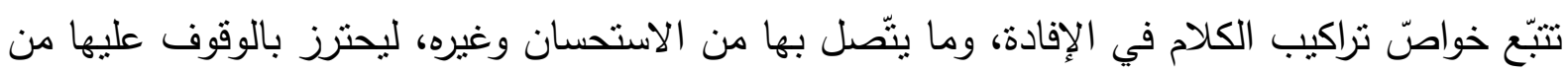

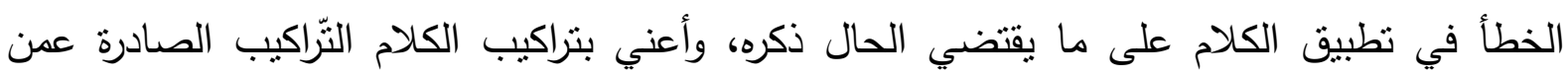
سواهم، لنزولها في صناعة البلاغة منزلة أصوات حيوانات تصدر عن محالها بحسب ما يتقّق، وأعني بخاصيّة الترّكيب: ما يسبق منه إلى الفهم عند سماع ذلك التّركيب، جارياً مجرى التّلزم له، لكونه صادراً

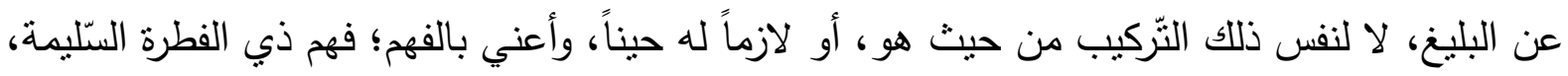

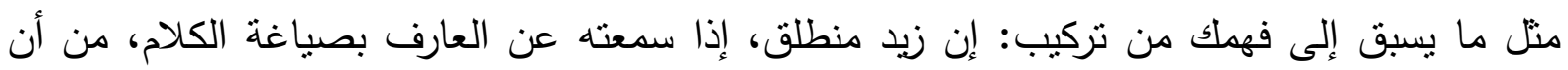

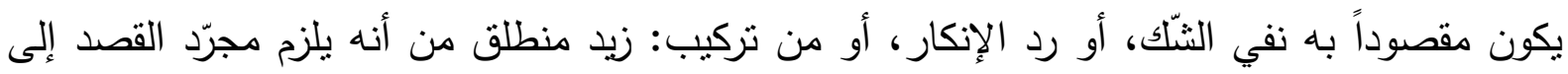

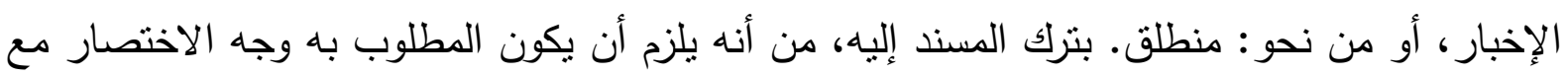

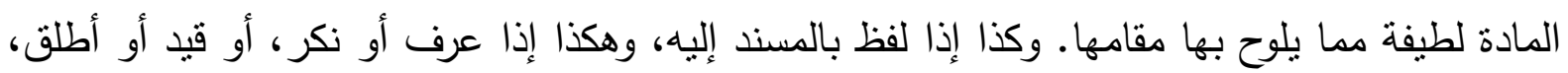

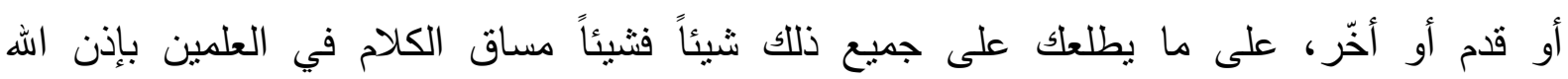

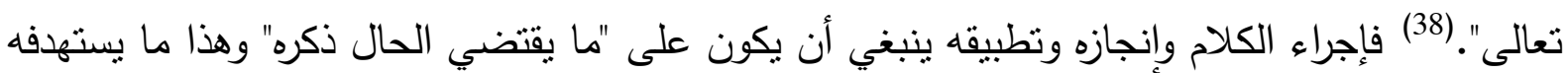
علم المعاني احترزاً من الوقوع في الخطأ. و"مراعاة المقامات والأحوال هي مدار الأمر في بلاغة الكلام/القول، وهو ما ما بعني أن يورد

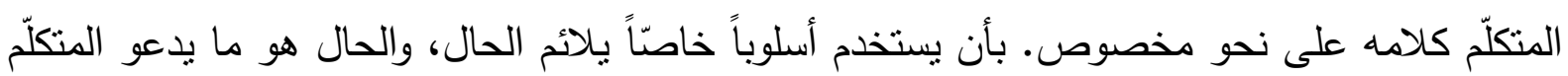

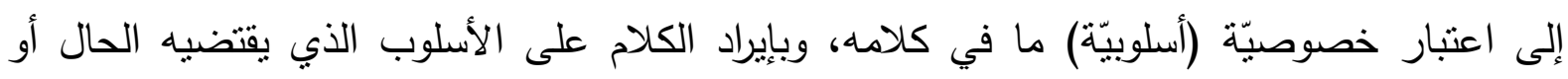

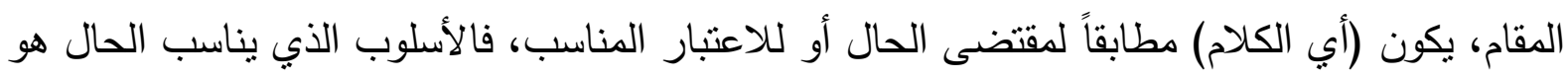

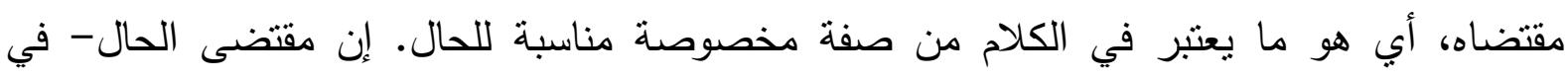

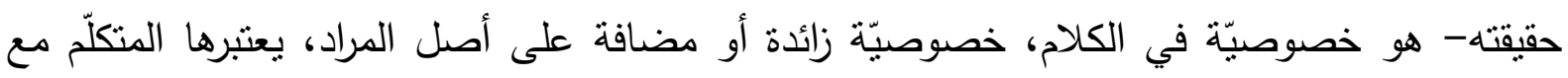

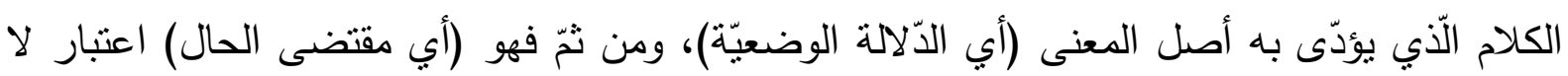

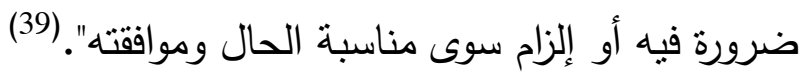
ويأتي تعريف المحدثين للبلاغة واضحاً، لا إثنكال فيه، ففي كتاب (البلاغة الواضحة) لعلي

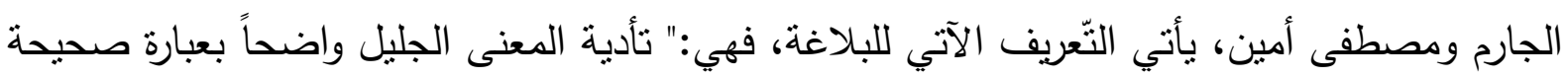

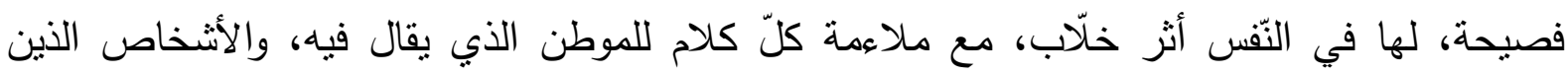
يخاطبون. "(40) 
يشترط التّريف ملاءمة الكلام للموطن أو المكان، والأشخاص المخاطبين، أو مطابقته، وهي

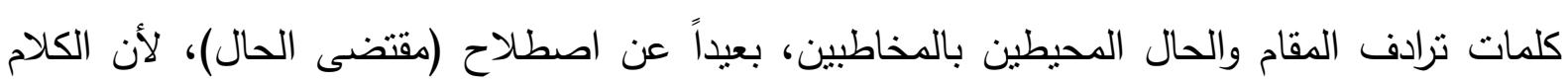
الملائم لمقامه وحاله يتضمن خصوصيّة ما استدعاه ذلك المقام أو الحال.

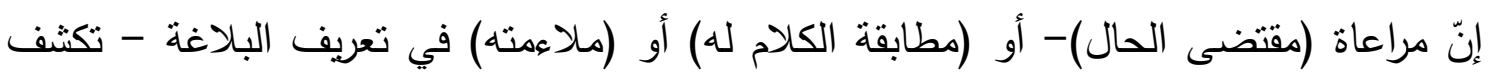

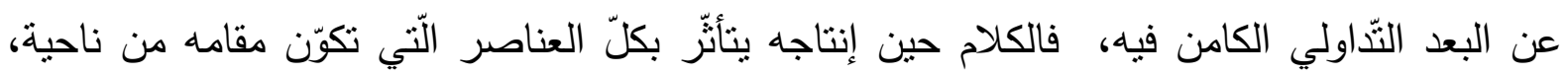

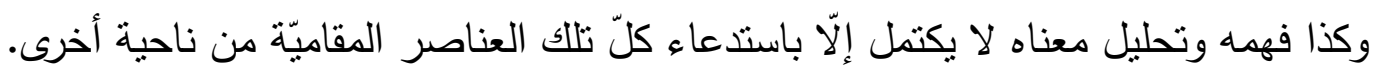

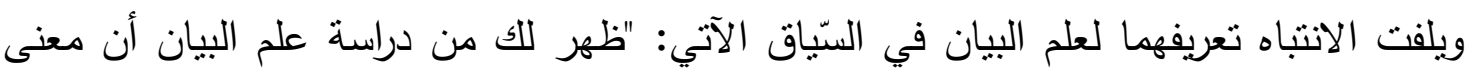

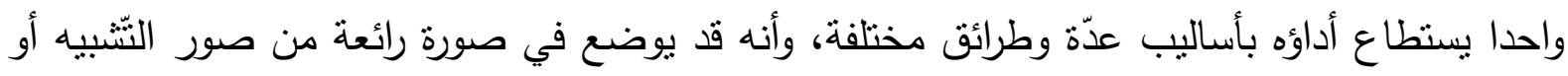

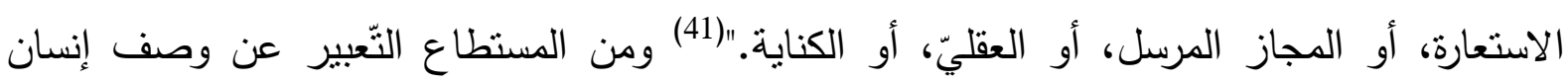
بالكرم بأربعة عشر أسلوباً، كل له جماله وحسنه وبراعته (422).

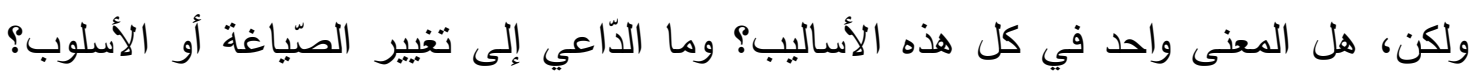

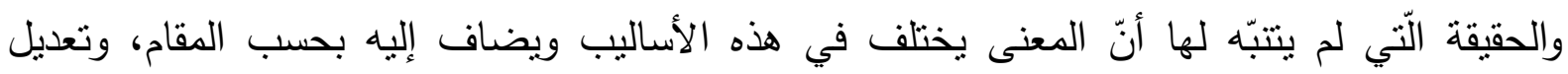

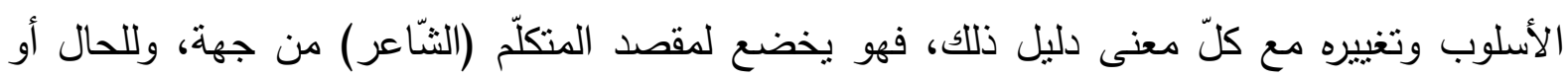

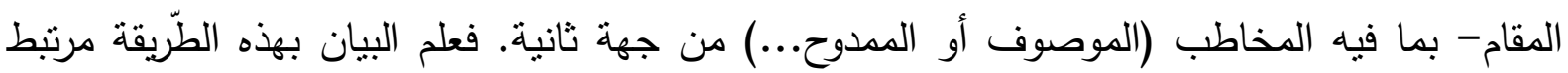

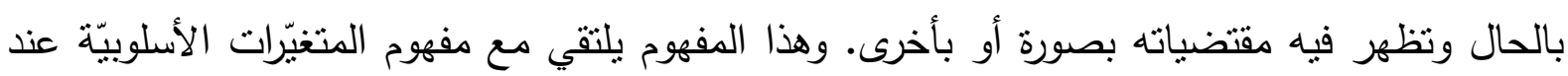
شارل بالي (43) بكيفيّة ما. وقد عالج محمد عبد المطلب الموضوع ذاته في كتابه (البلاغة العربيّة، قراءة أخرى) حين تعرّضه باله

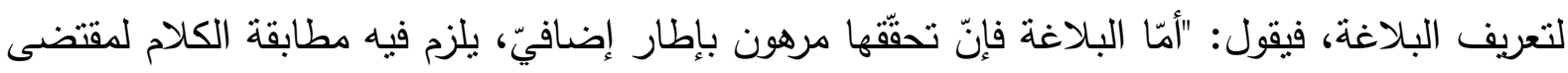

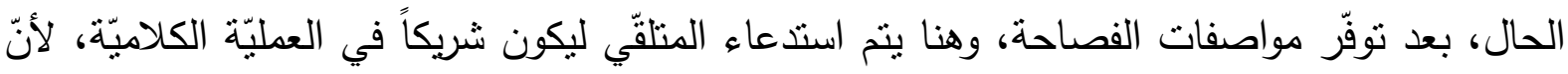

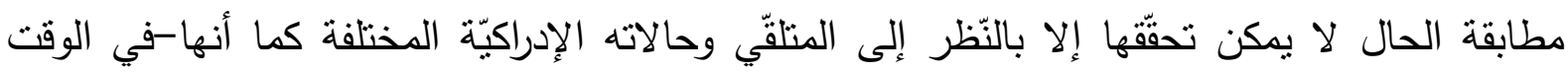

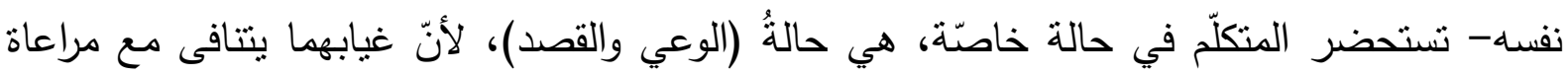

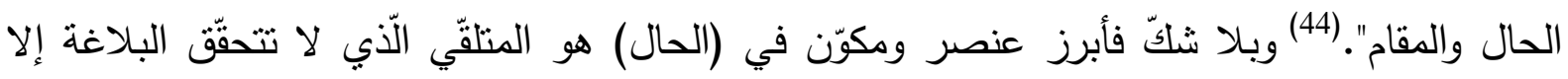

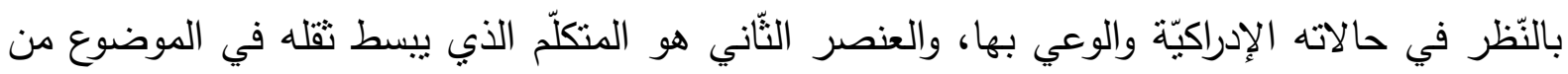

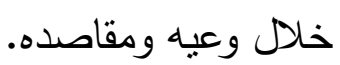

ويعتقد محمّد عبد المطلّب أنّ (مقتضى الحال) هو الكيفيّة التّي يتمظهر خلالها الكلام، فيقول:

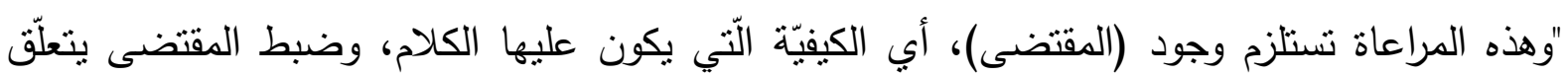

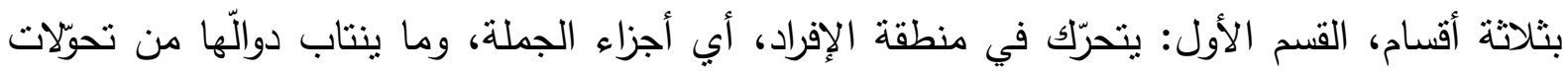

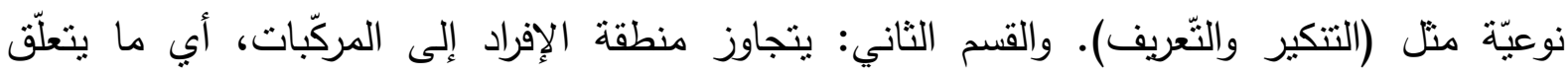

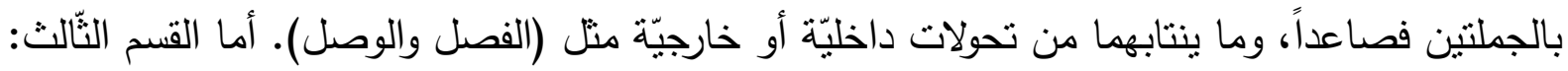

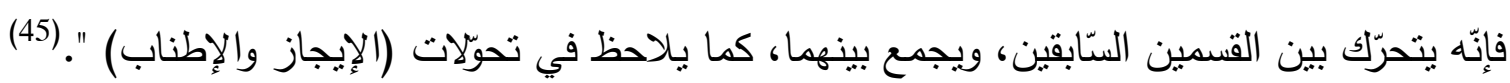


وينساءل محمّد عبد المطلب ويجيب: "ولكن ما المقصود (بمقتضى الحال) عند البلاغيين؟

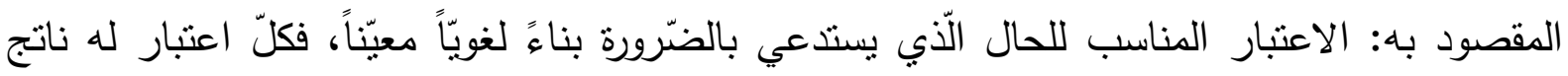

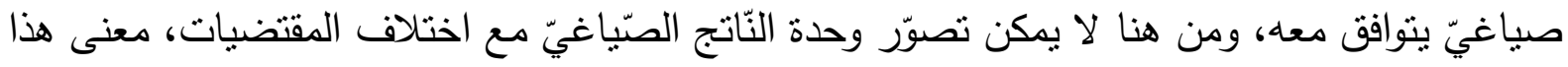

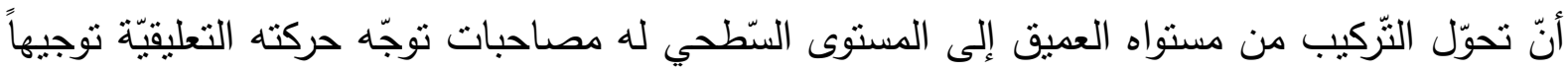

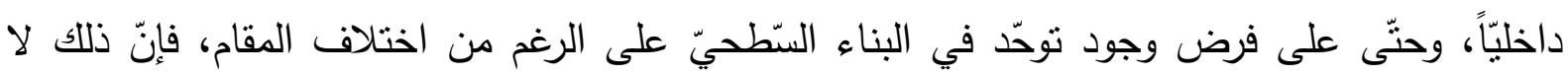

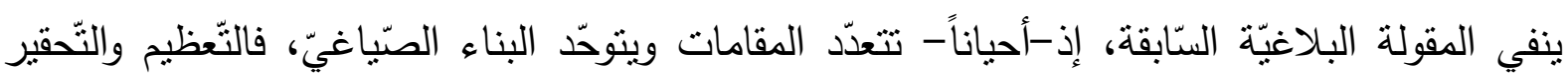

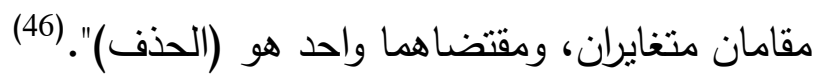

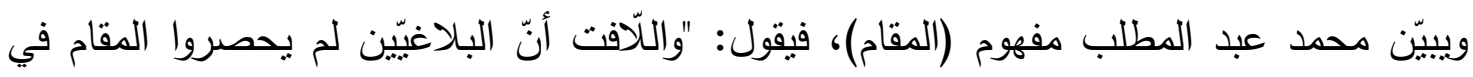

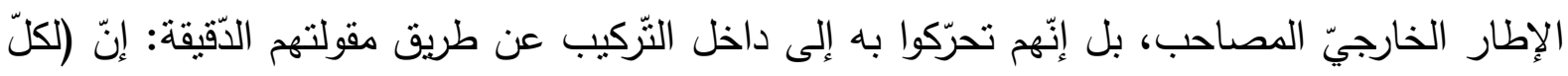

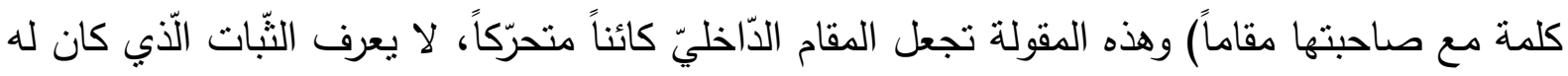
في الحالة الأولى المصاحبة". (47) والمقام، هنا، ما يطلق عليه بالسيّاق النّصي أو اللّغويّ.

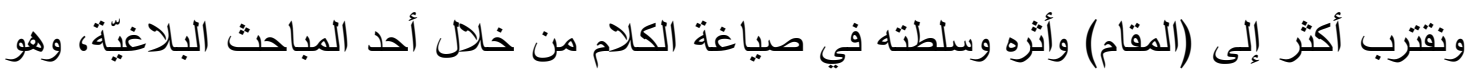
الخبر وما يتفرّع عنه فيما يأني.

\section{3}

من الواضح أنّ كثيراً من مباحث البلاغة تتعلّق بالمقام وعناصره من المتكلّم إلى المخاطب

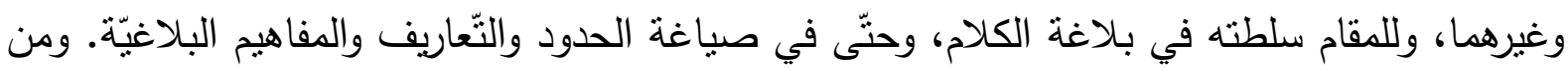

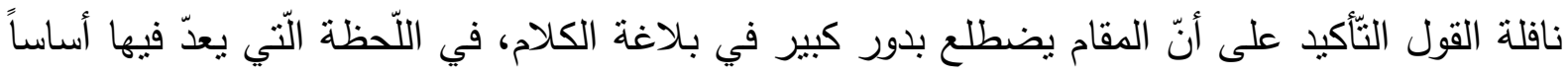

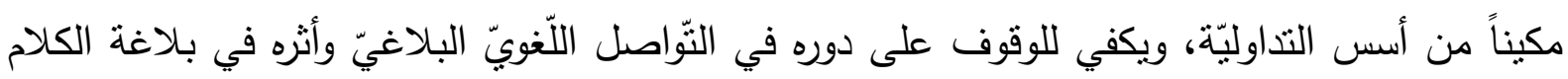

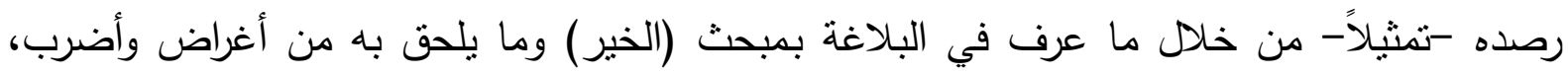

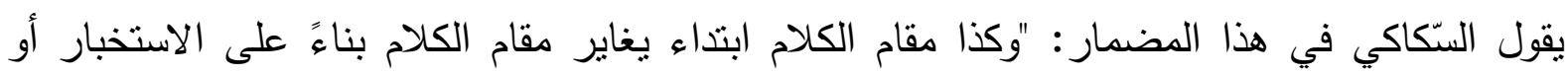

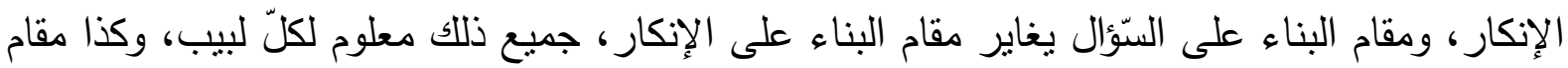

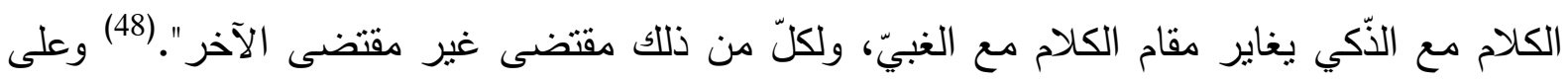

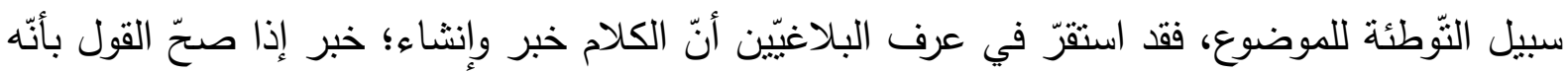

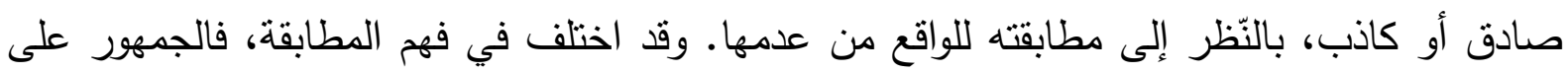

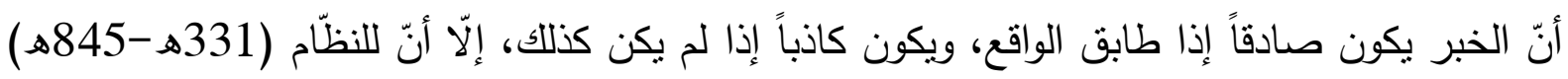

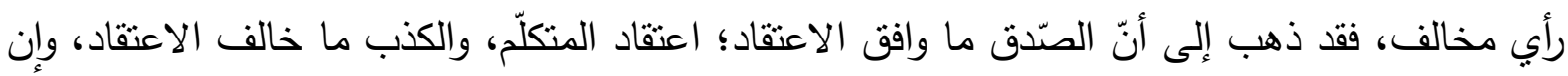

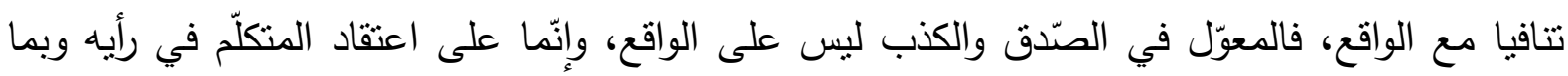

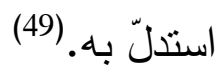


وذهب الجاحظ إلى أنّ الخبر ثلاثة أقسام: صادق وكاذب وثالث لا يوصف بالصنّق ولا بالكذب،

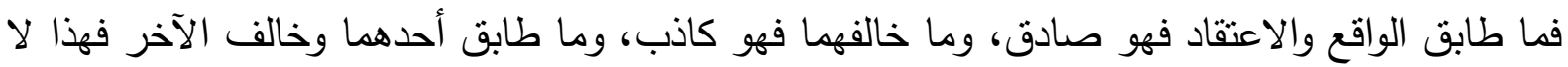

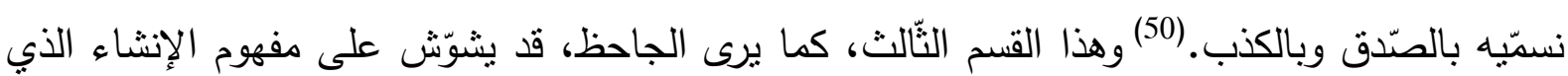

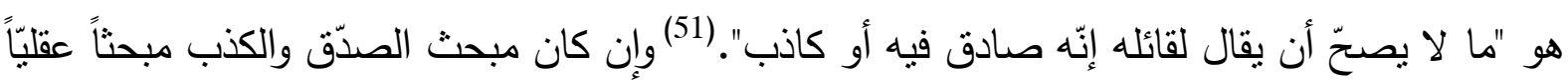
لا ترجى منه فائدة بيانيّة واضحة.

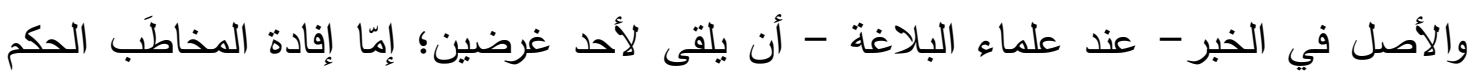

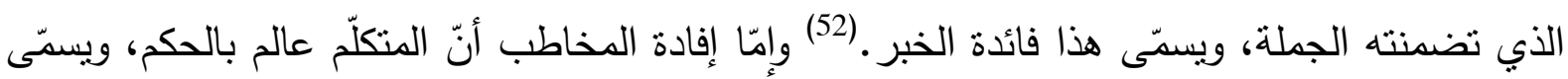

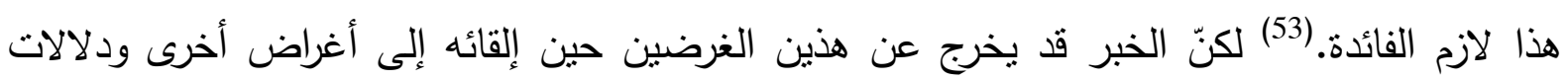

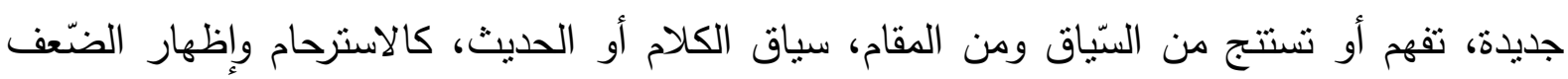

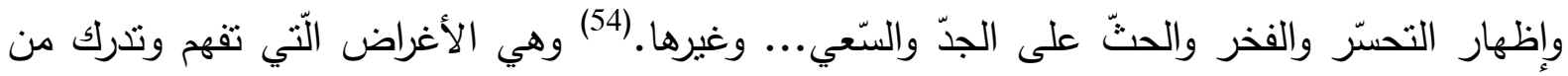

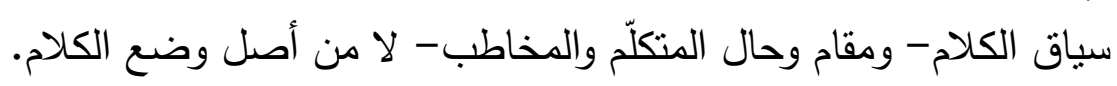

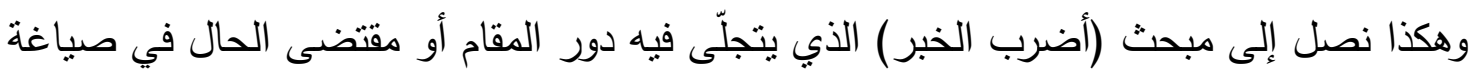

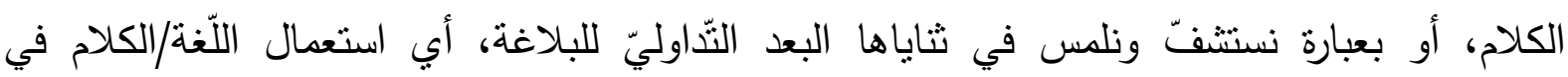

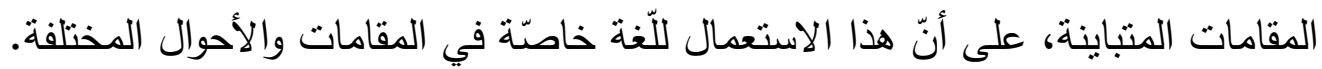

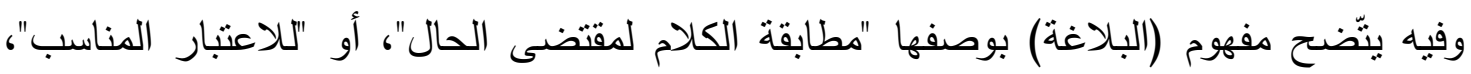

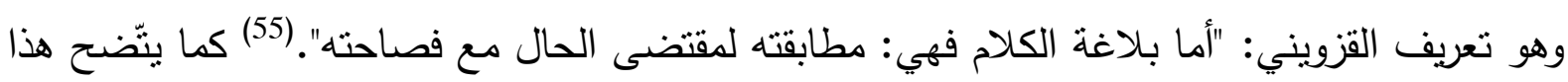

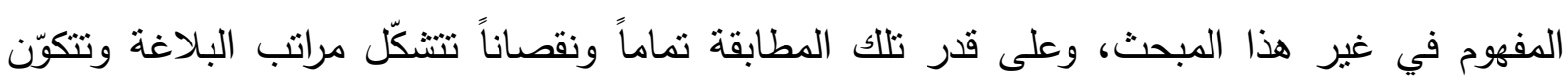
منازلها، فيرتفع شأن الكلام أو يسفّ. ويقول القزويني- وهو القول الدذكور أعلاه-: "ومقتضى الحال

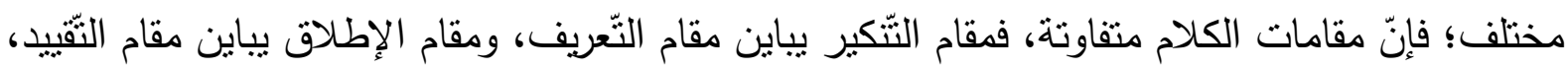

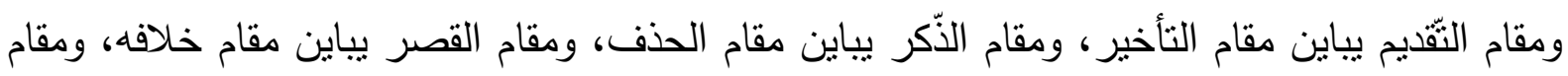
الفصل يباين مقام الوصل، ومقام الإيجاز يباين مقام الإطناب والمساواة، وكذا خطاب الفاب الذّكي يباين

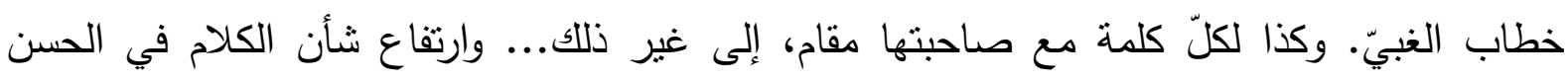
والقبول بمطابقته للاعتبار المناسب، وانحطاطه بعدم مطابقته له. فمقتضى الحال هو الاعتبار

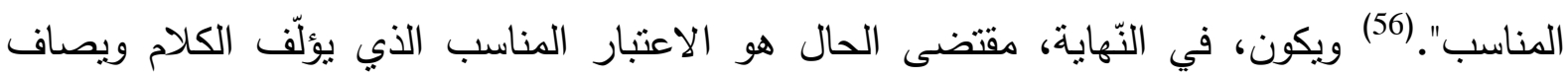
بحسب شروطه وقوانينه، وهو خصوصيّة نركييّة (لسانيّة وأسلوبيّة) في الكلام زائدة على أصل المئي المراد

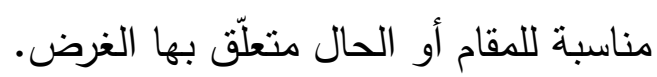
وتوضيحا لذلك، نقول: إنّ إلقاء الخبر أو استعمال الكلام يراعى فيه أحوال الدخاطبين الذّين

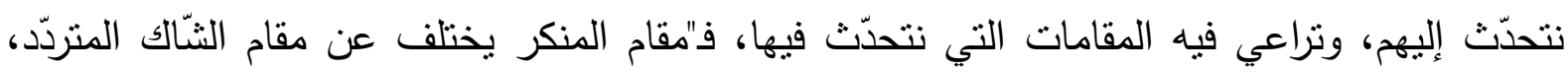

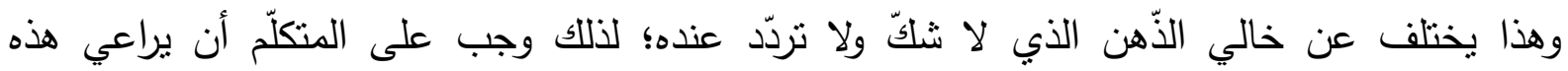

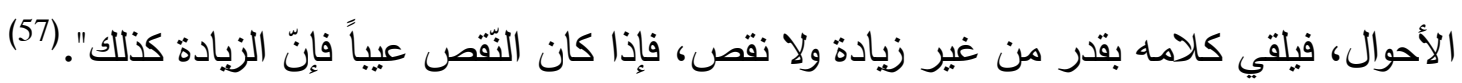


فللمخاطب، في هذا الباب، ثلاث حالات، تتبعها ثلاثة ضروب من الكلام (58):

- الحال الأولى (خلو الذّهن): يكون الدخاطب في هذه الحال خالي الذّهن من الحكم أو مضمون

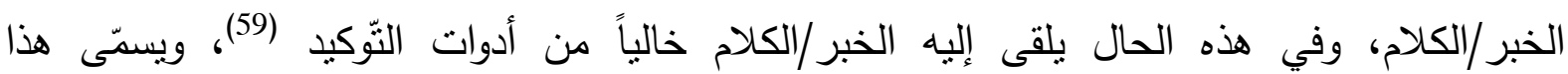
الضّرب/الأسلوب من الخبر/الكلام ابتدائيّاً.

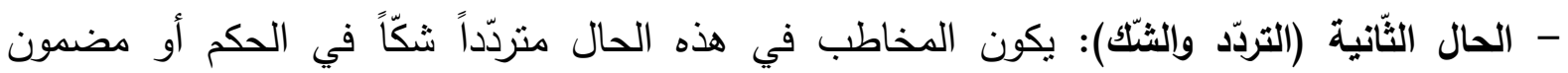

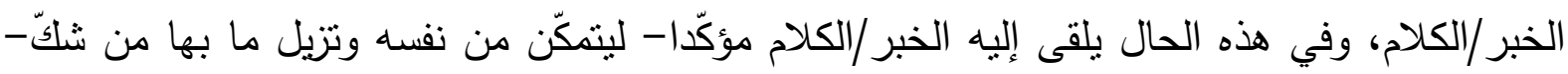
ويسمّى هذا الضّرب/الأسلوب طلبيّاً. وقد جعلوا التّوكبد، هنا، من باب الاستحسان.

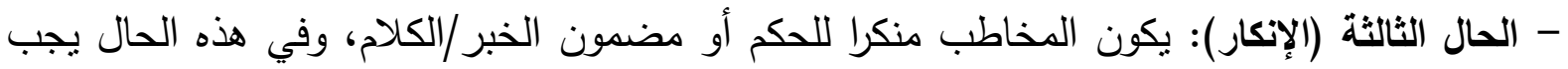

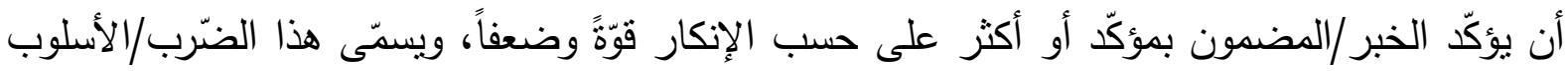
إنكاريّاً.

\section{وقد جعلوا التّوكيد، هنا، من باب الوجوب.}

فالمنكلّم في هذه الوضعيّة الثّّاصلية يصوغ كلامه بحسب الحال أو المقام أو المقتضى الذي يملي

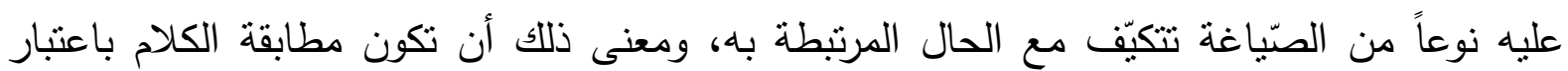

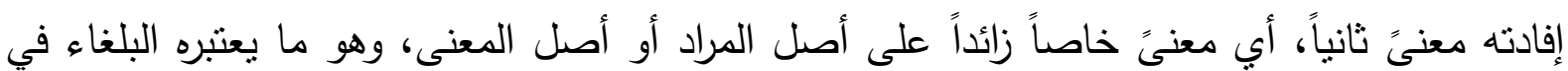

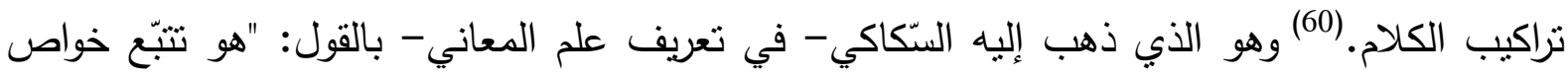

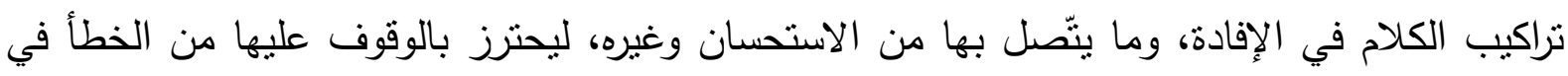
تطبيق الكلام على ما يقضي الحال ذكره، وأعني بتراكيب الكلام الترّاكيب الصّادرة عمّن سواهم، لنزولها في صناعة البلاغة منزلة أصوات حيوانات تصدر عن محالها بحسب ما يتّقن، وأعني بخاصيّة التزّكيب:

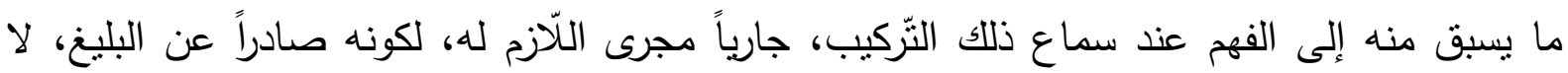

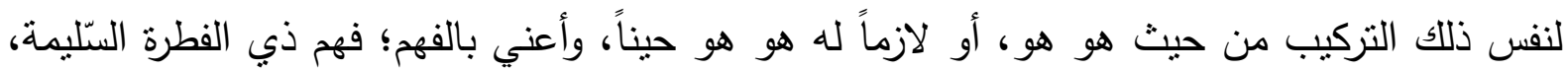

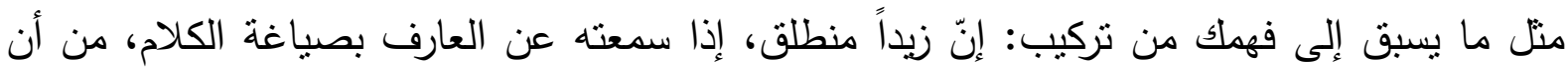

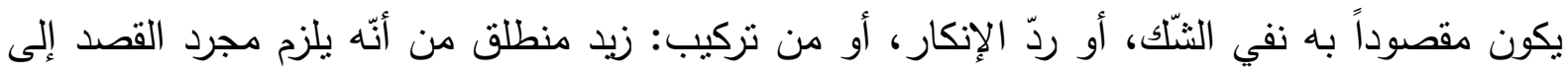

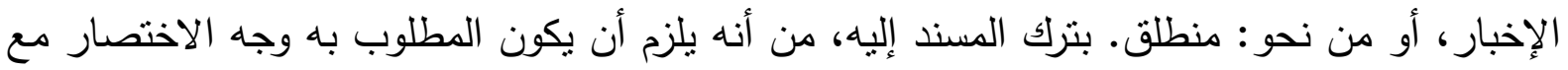

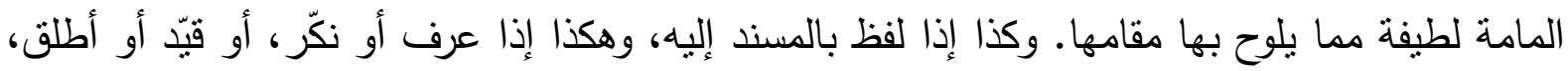

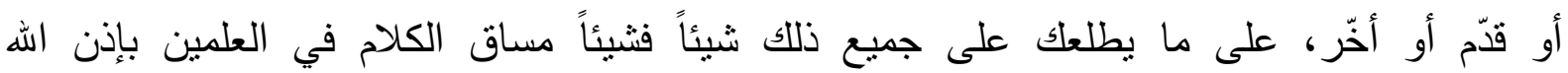
تعالى". (61)

ويتّضح أن المطابقة المنصوص عليها مرتبطة بالمعنى المقصود من الكلام أو الغرض الذي

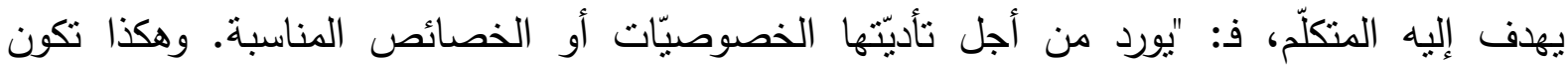


المطابقة، أو البلاغة بما هي مطابقة طريقة تأديّة المعنى (المراد)، أو الخصوصيّات المناسبة لتأديته،

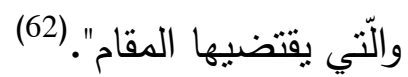

ويستتتج من ذلك أنّ تأديّة المعنى المراد بتلك الطّريقة والكيفيّة؛ أي الأسلوب هي المطابقة لمقتضى الحال، وهي البلاغة في نهاية الأمر.

5

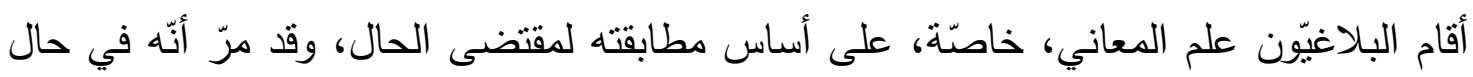

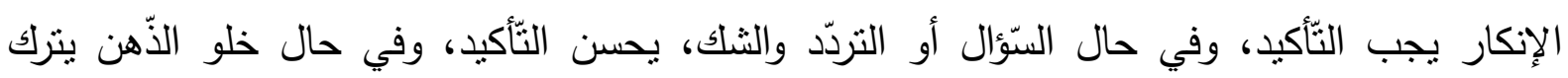

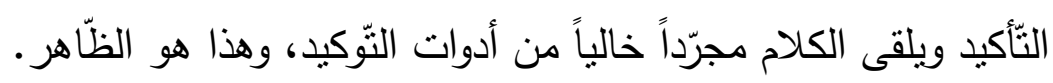

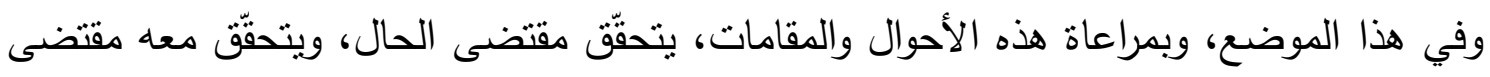

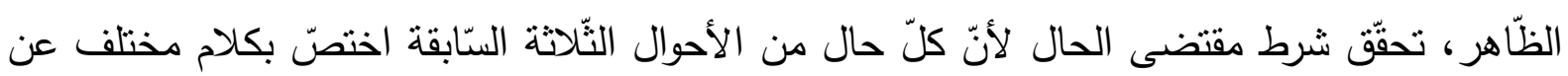

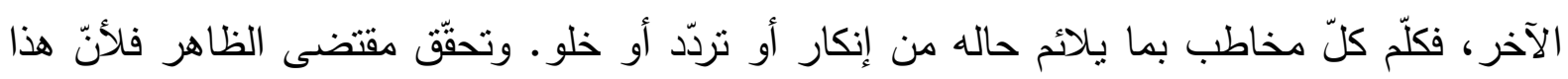

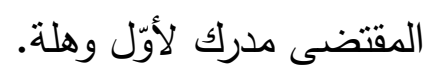

\section{1}

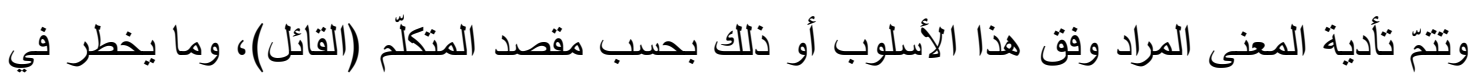

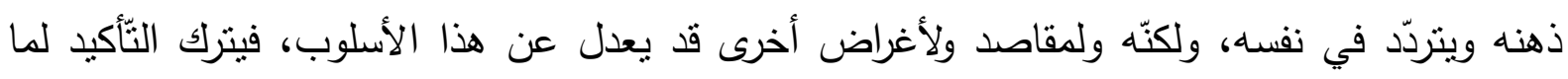

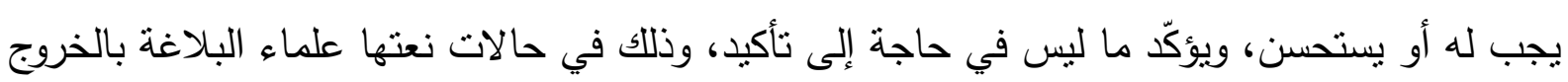

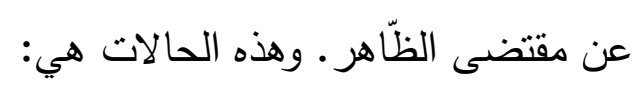

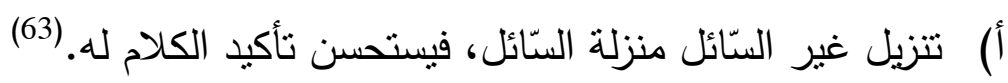

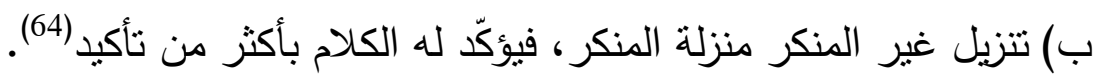

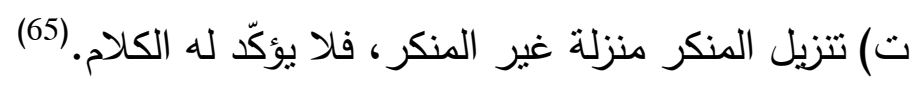
والملاحظ أنّ هذا الخروج قد نّّ ليس رغبة في تجاوز قواعد البلاغة، وإنّما مراعاة

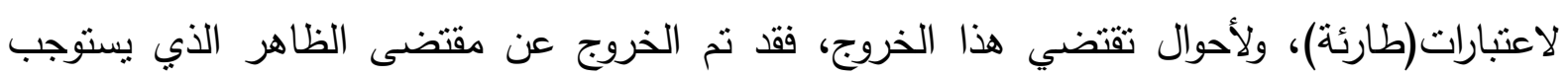

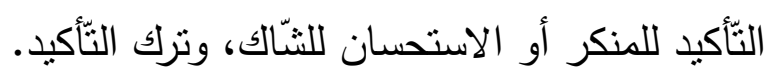
إذاً، فقد تحققّ مقتضى الحال، وهو شرط بلاغة الكلام، والخروج عليه خروج على حدّ البلاغة، وقد تمّ الخروج على مقتضى الظّاهر مراعاة لمقتضى الحال.

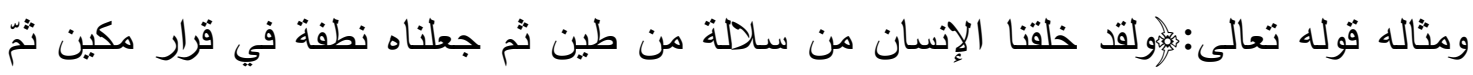

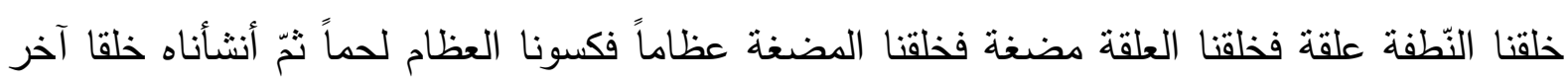

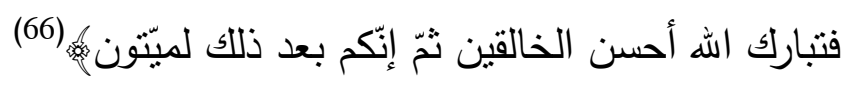




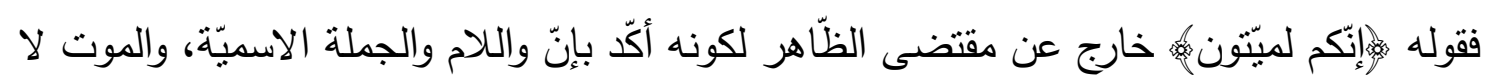

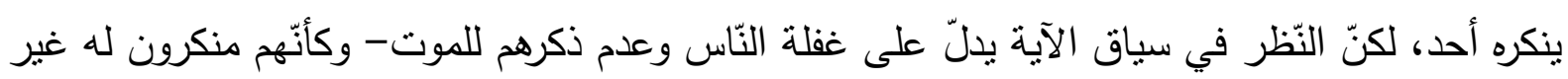

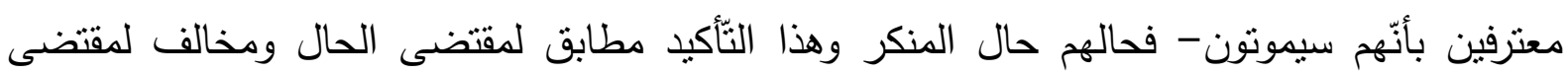
الظاهر . (67) بأنمين

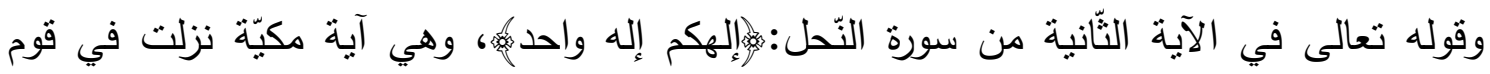
منكرين لوحدانية الله، خارج عن مقتضى الظّاهر لتجرّده من التّأكيد، وداخل في مقتضى والَّل الحال، فوحدانيّة

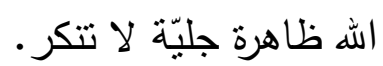

\section{2 خروج الكلام وعدم مطابقته لمقتضى الحال خروج عن البلاغة}

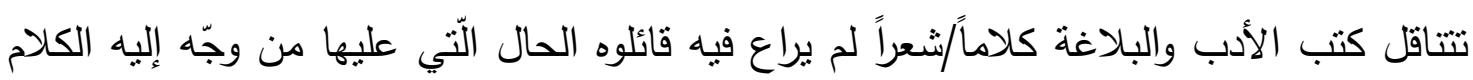

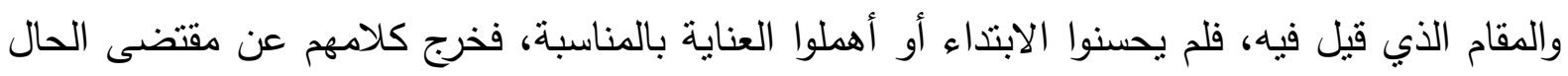

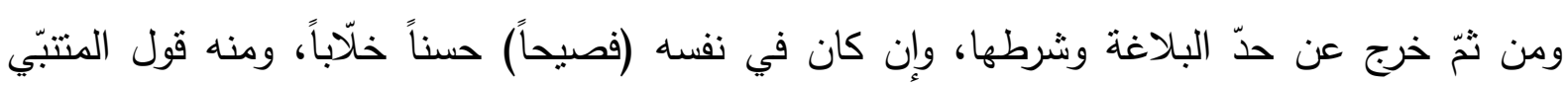
لكافور الإخشيديّ في قصيدة ددحه بها، بلغت سبعة وأربعين بيناً، والتّي جاء في مطلعها (68):

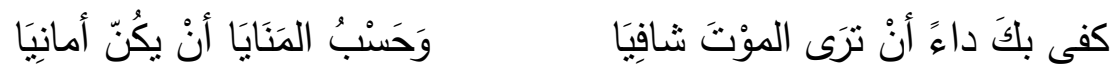

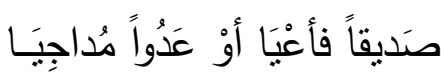

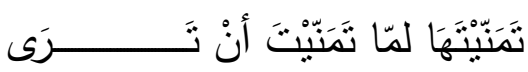

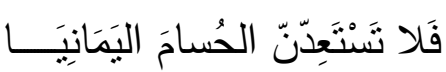

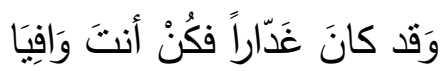

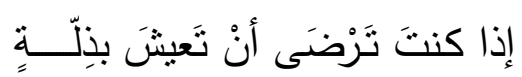

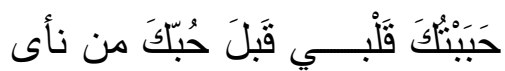

وقوله في قصيدة بائية قالها في مدح كافور ومطلعها(69):

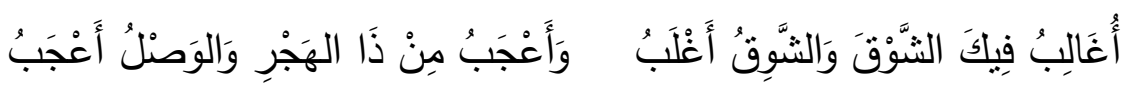

$$
\text { ومنها الأبيات:(70) }
$$

لقد كنتُ أرْجُو أنْ أرَاكَ فأطرَبُ

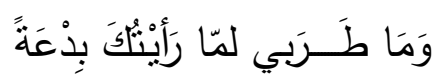
كأنّي بمَذْحِ قَبَلَ مَذْحِكَ مُنْنِبُ

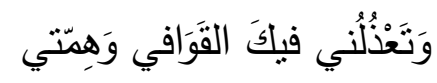

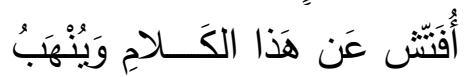

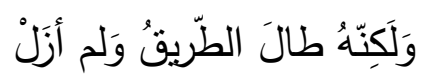

قال الواحديّ (توفي سنة 468هـ): هذا البيت يثبه الاستهزاء فإنّه يقول طربت عند رؤيك كما يطرب الإنسان لرؤية المضحكات. قال ابن جنّي (ت 392هـ): لمّا قرأت على أبي الطّيب هذا البيت قلت فلت 
له: ما زدت على أن جعلت الرّجل قرداً، فضحك.(71) وقد ذكر عبد الرحمان البرقوقي ما هو قريب من

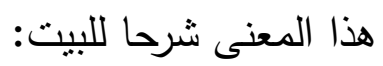

\section{ومنتلك يُؤتى من بلاد بعيدةٍ ليضحك ربّات الحداد البواكيا}

إذ قال: "ربات الحداد: أبي الثّاكلات اللّابسات الحداد- وهي ثياب سود يلبسها النّاء: ربّات الحجال، والحجال: الستّور • ويقول: إنكّك عجب من رآه ضحك، ومناك يقصد من البلاد النّائيّة ليتعجّب

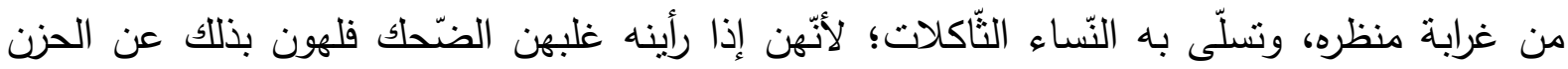

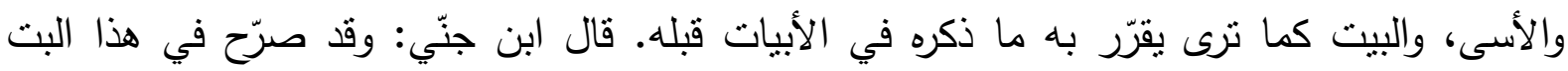
بجميع ما كان أخفاه في مدحه بقوله في إحدى مدائحه الكافوريّة:

وَما طَرَبِي لمّا رأينتاك بِدْعَةً

ومن ذلك أن أبا النّجم الفضل بن قدامة دخل على هشام بن عبد الملك(71 هـ -125هـ)، وأنشده:

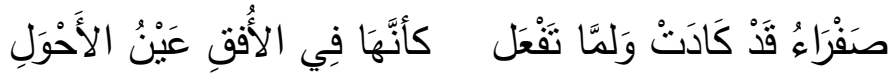

وكان هشام أَحْوَلَ فأمر بحبسه.(73) ومدح جرير (33- 110هـ) عبد الملك بن مروان (26هـ -86هـ) بقصيدة جاء في مطلعها:

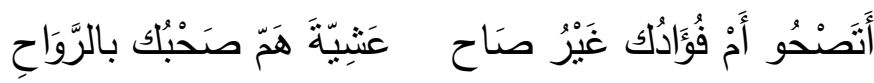

فأنكره عبد الملك، وقال له: بل فُوُادُّك أنْتَ. (74)

ومن ذلك قول البحتري (205 - 284هـ) في قصيدة ينشدها أمام ممدوحه (أبي سعيد) بدأها ب:

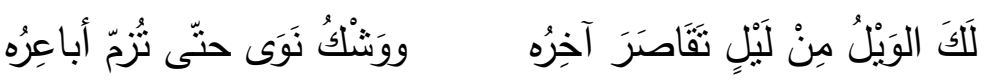
فقال المدوح أبو سعيد: بل الويل والحرب للك. وغير ذلك من الكلام شعراً ونثراً الذي لم يحظ بالقبول، مع فصاحته، لإخلافه بشرط البلاغة في مطابقته لمقتضى الحال. إن هذه النّصوص الأدبيّة التّي يدرجها البلاغيّون في خروج الكلام وعدم مطابقته لـقتضى الحال، لتهال

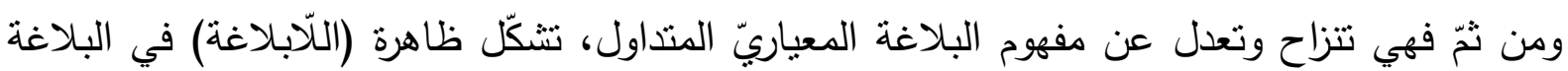

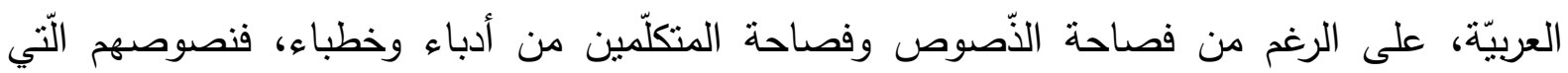
خالفت شروط البلاغة غير بليغة، فالمتتبي وأبو النّجم وجرير والبحتري في قصائدعم المشار إليها سابقاً 
غير بلغاء. وبناء عليه فالنّص الفصيح مرتبة والنصّ البليخ مرنبة أخرى على مرتبة الفصاحة، وبتوضيح

$$
\begin{aligned}
& \text { البلاغة= الفصاحة + البلاغة. } \\
& \text { اللّببلاغة= الفصاحة - البلاغة. } \\
& \text { أمّا الفصاحة فهي: } \\
& \text { (الفصاحة)= الفصاحة + أو - البلاغة. }
\end{aligned}
$$

فالبلاغة تقتضي مقتضى الحال، وهو الحقيقة التّاولية الكامنة فيها، والفصاحة لا تقتضيه.

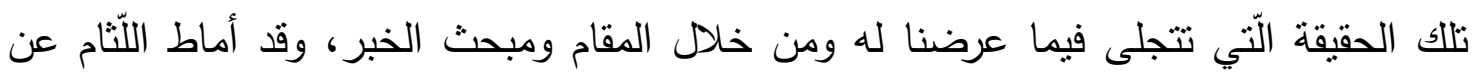

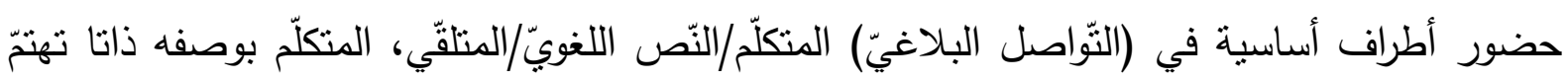

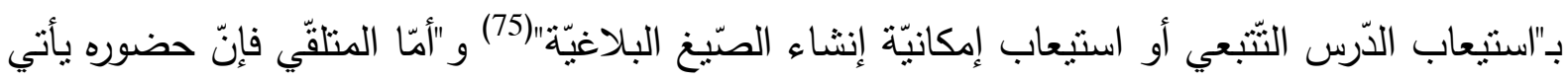

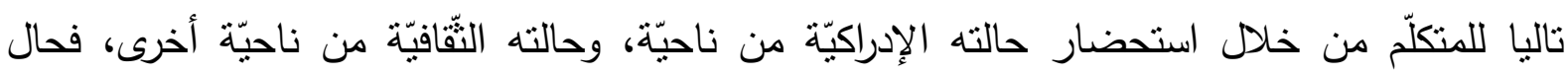

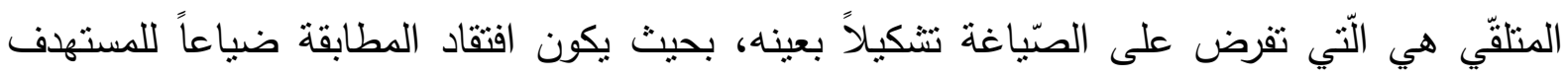

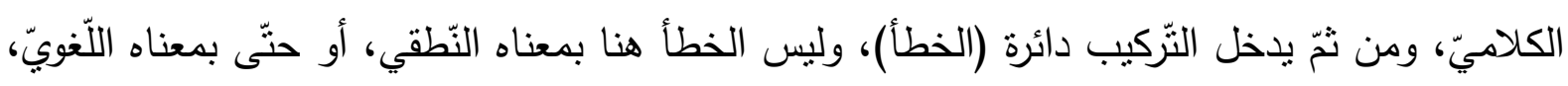

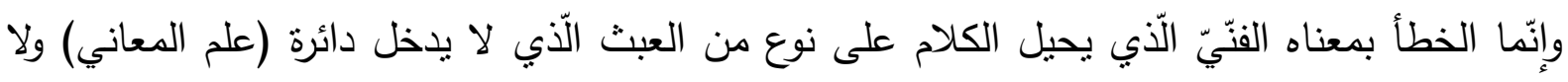

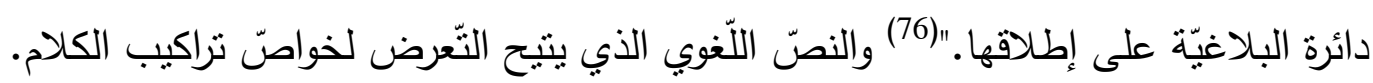

\section{6}

لم ينته دور البلاغة ولم تفقد كلّ دررها، فهي تمتلك قدرة ذاتيّة على النّّدّد والتكيّف مع المعارف

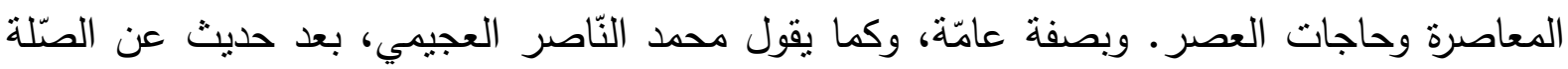

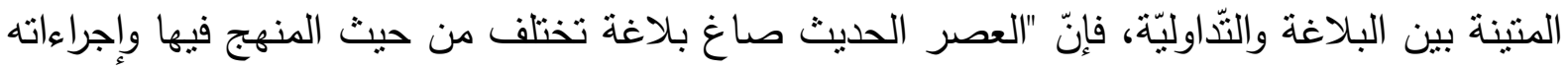

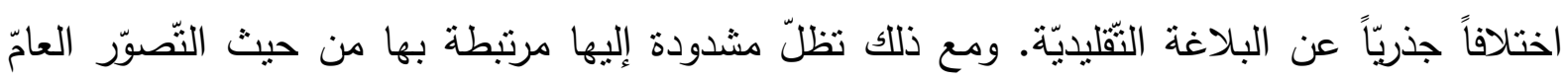

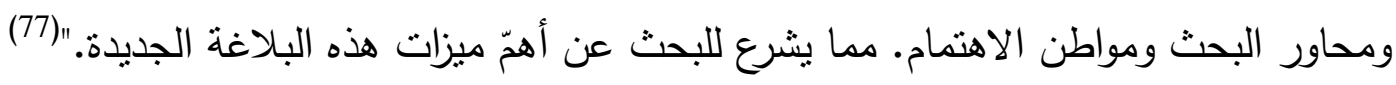

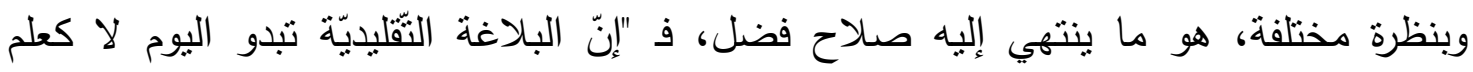

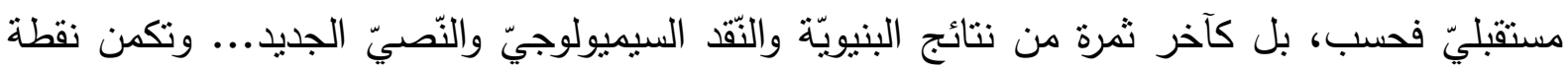

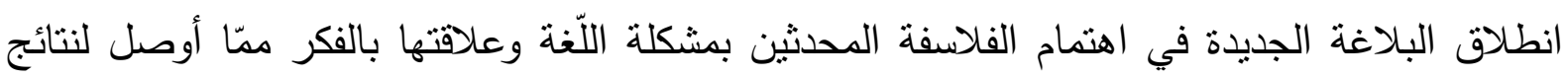

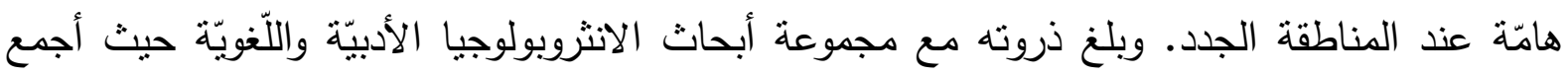

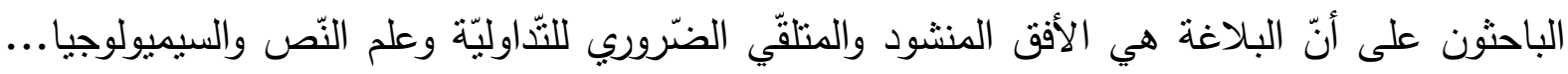

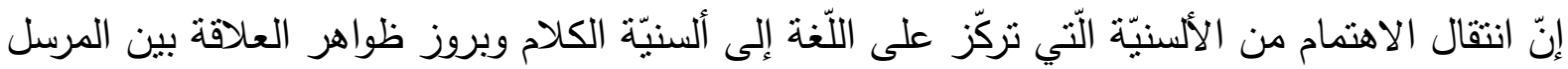


والمتلقيّ في مجال التّاوليّة قد حدا بكثير من علماء اللّغة إلى العودة إلى البلاغة."(78)

\section{7}

لتلخيص ما سبق، يمكن التأكيد على الأمور التالية:

- حضر الاشتغال التّاوليّ في البلاغة العربيّة بشكل واضتح وفي كل علومها المتعارف عليها، وبخاصة (علم المعاني)، فكثير من مباحث البلاغة يحضر فيها هذا الاشتغال ويحظى بأهميّة كبيرة، من خلال فكرة (مطابقة الكلام لمقتضى الحال) وفكرة (المقام) كما يتجلّى ذلك في مفهوم (البلاغة) ذاتها. - أتاحت فكرة (المقام) في البلاغة لعلوم جديدة، كالتّاولية، لنتترك معها في كثير من المفاهيم والرّؤى

وتحدّد منطلقاتها ومجالات بحثها، بما في ذلك المقام والسّيّاق ومجموع العناصر التي تشكل التواصل. - تتبيّن أصالة المقام في الدرّ البلاغي فيما أكدّ عليه علماء البلاغة من خلال الإشارة إلى المقام، بمعنييه، والالتزام بمقتضى الحال والاعتبار المناسب، وكذلك من خلال الخروج على مقتضى الظاهر وغيرها من الموضوعات التي لقيت عناية لدى علماء البلاغة تتظيراً وتطبيقاً، وما نراه في علم المعاني والإسناد الخبري مثنال واضح لما نؤكّده. - إفادة التداولية المعاصرة من المعطيات العلمية البلاغيّة والنقديّة وغيرهما.

مصادر ومراجع

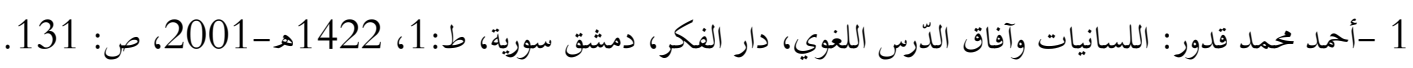

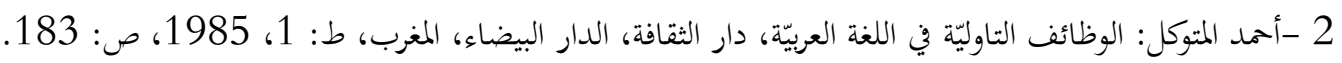

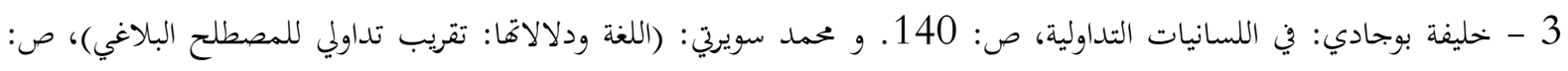

4- خليفة بو جادي: في اللسانيات التداولية، ص:

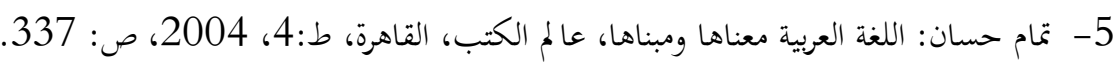

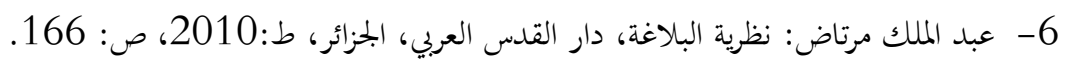

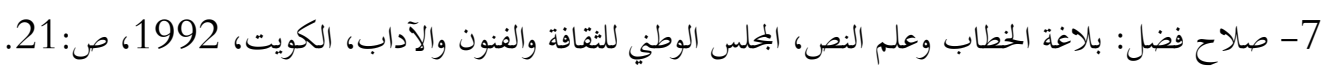

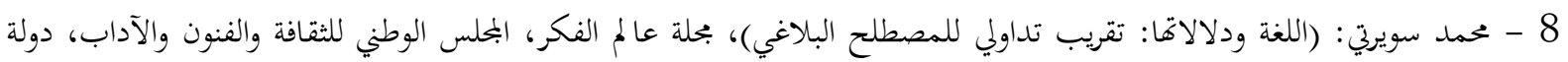

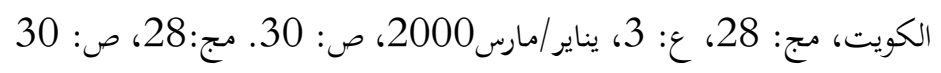

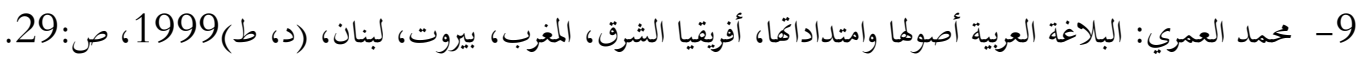

$$
\begin{aligned}
& \text { 10- المرجع نفسه، ص: 11- } 30 . \\
& \text { 11- المرجع نفسه، ص: 12- إمع نفس، ص: } 30 . \\
& \text { 12- المرجع نفسه، ص: 13 } 30 . \\
& \text { 13- المرجع نفسه، ص: المرجه، صن: } 32 .
\end{aligned}
$$


14 - محمد عبد المطلب: البلاغة العربية قراءة أخرى، ص: 21 - 15.

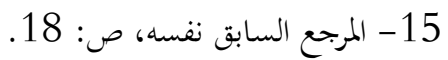

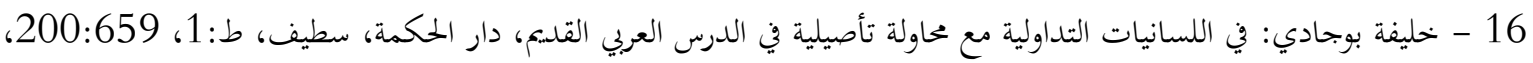

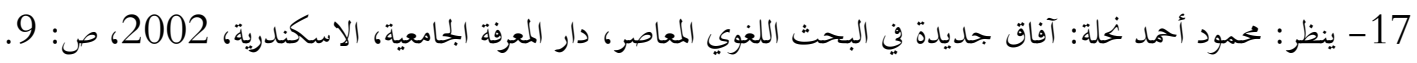

18- المرجع نفسه، ص: 19 11.

19- المرجع نفسه، ص: 12

20 - المرجع نفسه، ص: 14

21- 21 المرجع نفسه، ص: 14.

22- عبد الهادي بن ظافر الشهري: استراتيجيات الخطاب مقاربة لغوية تداولية، دار الكتاب الجحديد المتحدة، بيروت، لبنان، ط:1، 2004، ص:22.

23- شكري الطوانسي: (المقام في البلاغة العربية: دراسة تداولية) بحلة عالم الفكر، المخلس الوطني للثقافة والفنون والآداب، الكويت

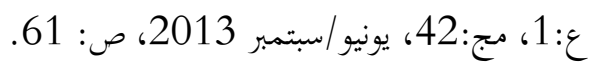

24- المرجع نفسه، ص: 60

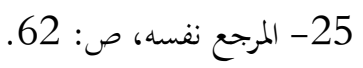

26- المرجع نفسه، ص: 65.

27- عبد الهادي بن ظافر الشهري: استرتيجيات الخطاب، صن:

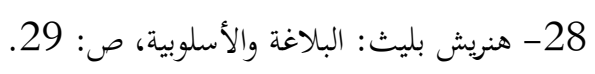

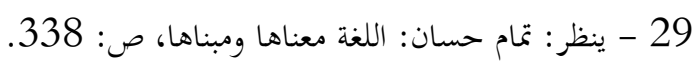

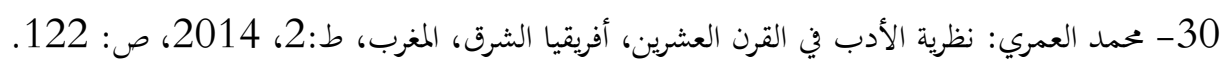

31 - 31 المرجع نفسه، ص: 122

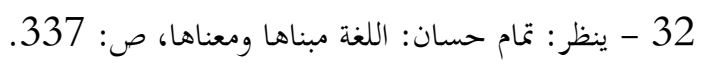

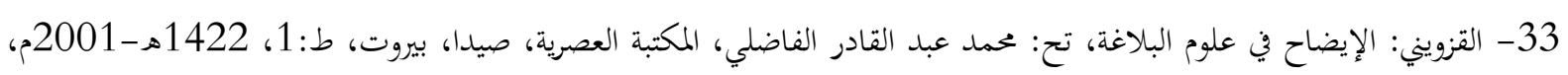

34- المرجع نفسه، ص: 17

35 - المرجع نفسه، ص: 23

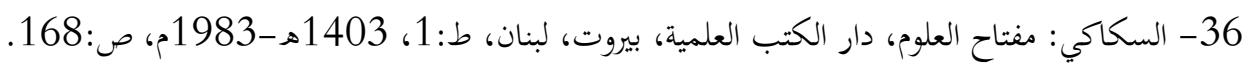

37- المرجع السابق، ص: 38 169.

38- المرجع نفسه، ص: 39 - 38 162.

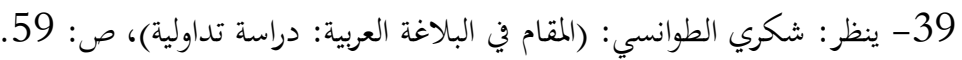

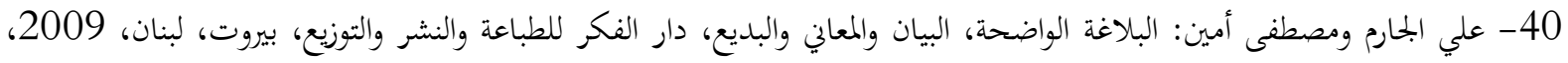

41- المرجع نفسه، ص: 112.

42- المرجع نفسه، ص: 41 المرجع نفس، ص: 114 وما قبلها.

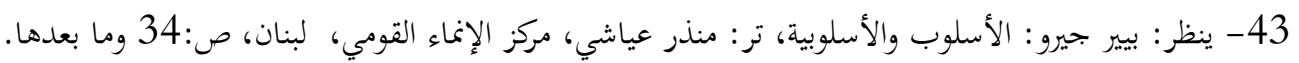

44 - محمد عبد المطلب: البلاغة العربية، قراءة أخرى، ص: 70 : 70. 
45

46 - المرجع نفسه، ص: 71 - 71 المع نفس، ص:

47- المرجع نفسه، ص: 41 71 - 48

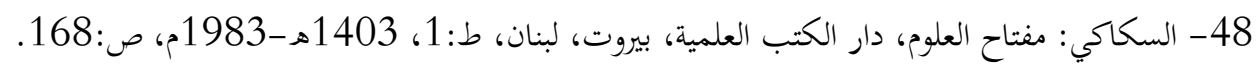

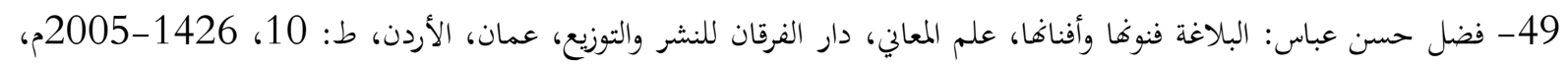
ص: 104.

50- المرجع نفسه، ص: 107.

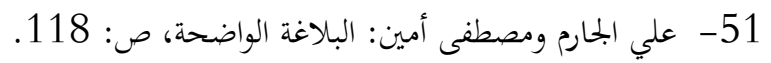

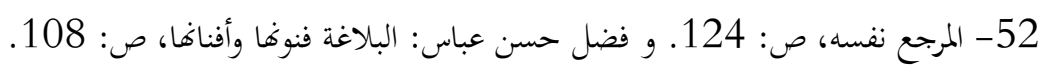

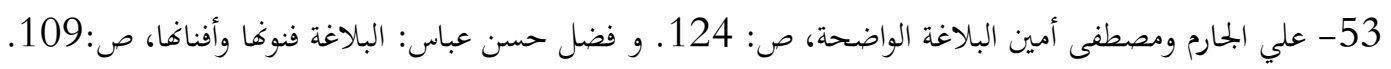

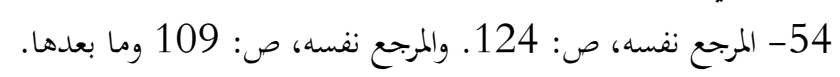

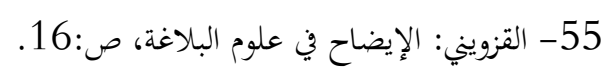

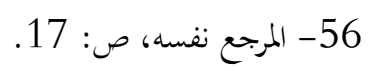

57- فضل حسن عباس: البلاغة فنوها وأفناها، ص: 109

58- ينظر هذا المبحث في كتب البلاغة مثلا: فضل حسن عباس: البلاغة فنوها وأفناها، ص: 115. 115. وعلي الجارم ومصطفى أمين:

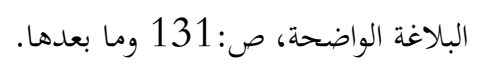

59- أدوات التوكيد هي: إنّ، لام الابتداء، ضمير الفصل، القسم، إمّا الشرطية، حرفا التببه(ألا، أما)، الحروف الزائدة(إن، أن، ما ، من، إنها،

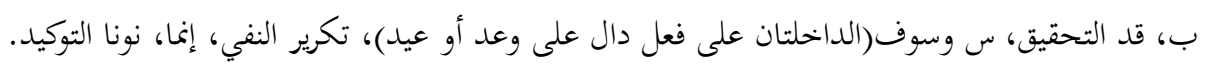

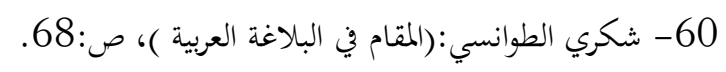
61 - 61 السّكاكي: مفتاح العلوم، ص : 162

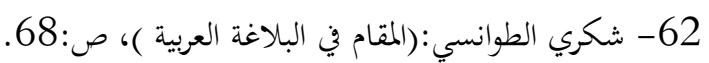

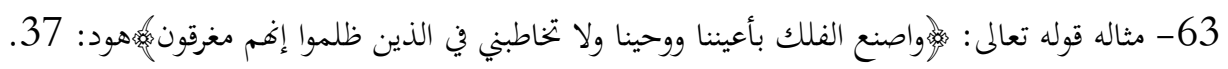

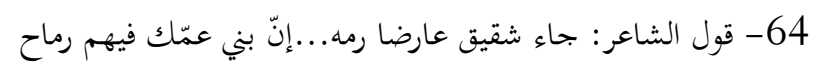

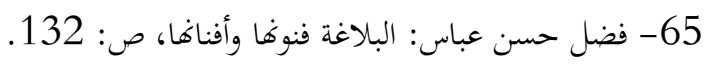

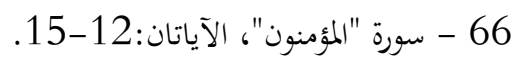

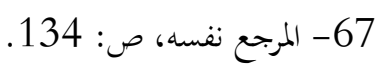

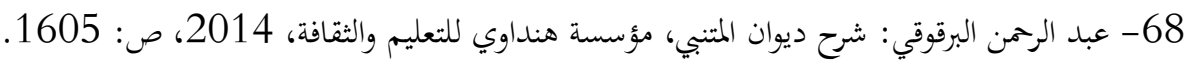

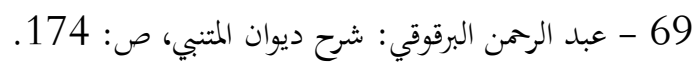

70

71 - علي الجارم ومصطفى أمين: البلاغة الواضحة، ص: 910

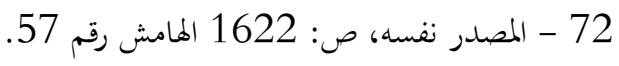

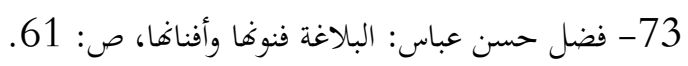

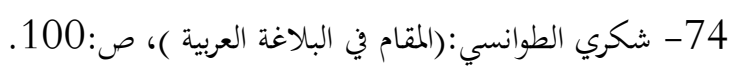

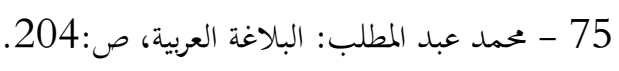

76 - المرجع نفسه، ص: 205. 
77- محمد النصار العجيمي: النقد الأدبي العربي الحديث ومدارس النقد الغربية، دار محمد علي الحامي، تونس، ط:1، 1998، ص:

الجارم (علي) وأمين (مصطفى): البلاغة الواضحة، البيان والمعاني والبديع، دار الفكر للطباعة والنشر والتوزيع، بيروت، لبنان،

العمري (محمد): البلاغة العربية أصولها وامتداداتها، أفريقيا الشرق، المغرب، بيروت، لبنان، (د، ط) 1999.

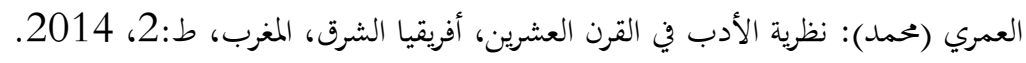

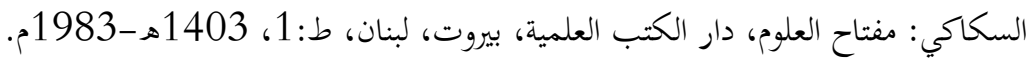

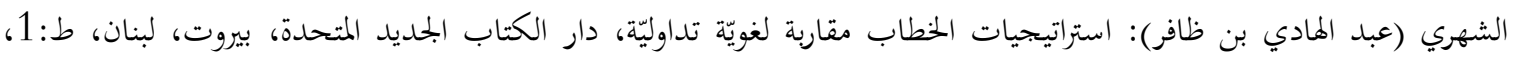

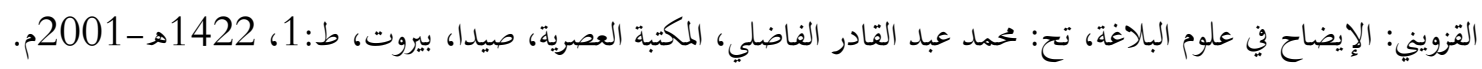

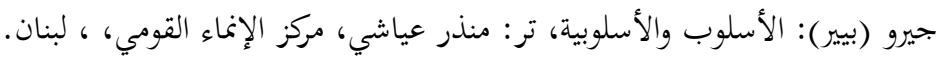

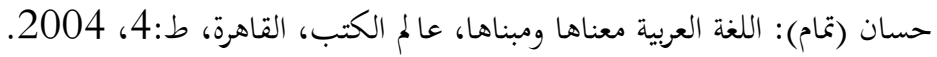

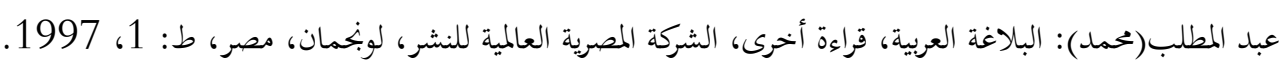

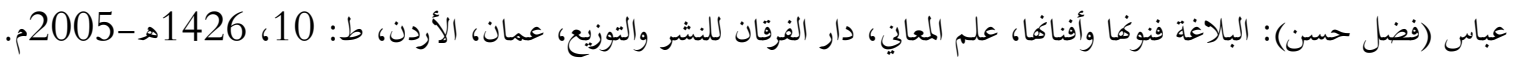

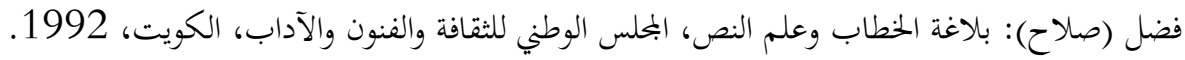

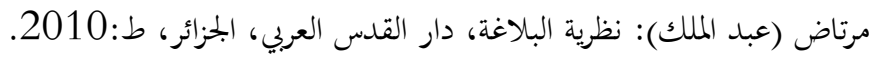
نحلة (محمود أحمد): آفاق جديدة في البحث اللغوي المعاصر، دار المعرفة الجامعية، الاسكندرية، 2002.

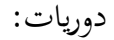
13-الطوانسي (شكري): (المقام في البلاغة العربية: دراسة تداولية، بحلة عالم الفكر، المحلس الوطني للثقافة والفنون والآداب، الكويت ع:1:، مج:42، يونيو/سبتمبر 2013. 